\title{
Chemical characterization of springtime submicrometer aerosol in Po Valley, Italy
}

\author{
S. Saarikoski ${ }^{1}$, S. Carbone ${ }^{1}$, S. Decesari ${ }^{2}$, L. Giulianelli ${ }^{2}$, F. Angelini ${ }^{2}$, M. Canagaratna ${ }^{3}$, N. L. Ng ${ }^{3}{ }^{*}$, A. Trimborn $^{3}$, \\ M. C. Facchini ${ }^{2}$, S. Fuzzi ${ }^{2}$, R. Hillamo ${ }^{1}$, and D. Worsnop ${ }^{1,3,4}$ \\ ${ }^{1}$ Finnish Meteorological Institute, Air Quality, Helsinki, Finland \\ ${ }^{2}$ Institute for Atmospheric Sciences and Climate (ISAC), National Research Council (CNR), Bologna, Italy \\ ${ }^{3}$ Aerodyne Research, Inc. Billerica, MA, USA \\ ${ }^{4}$ University of Helsinki, Department of Physics, Helsinki, Finland \\ *now at: Georgia Institute of Technology, School of Chemical and Biomolecular Engineering and School of Earth \\ and Atmospheric Sciences, Atlanta, GA, USA
}

Correspondence to: S. Saarikoski (sanna.saarikoski@fmi.fi)

Received: 12 March 2012 - Published in Atmos. Chem. Phys. Discuss.: 28 March 2012

Revised: 29 August 2012 - Accepted: 29 August 2012 - Published: 19 September 2012

\begin{abstract}
The chemistry of submicron particles was investigated at San Pietro Capofiume (SPC) measurement station in the Po Valley, Italy, in spring 2008. The measurements were performed by using both off-line and on-line instruments. Organic carbon (OC) and elemental carbon, organic acids and biomass burning tracers were measured off-line by using a 24-h $\mathrm{PM}_{1}$ filter sampling. More detailed particle chemistry was achieved by using a Aerodyne high resolution time-offlight aerosol mass spectrometer (HR-ToF-AMS) and analyzing the data by positive matrix factorization (PMF). Oxalic acid had the highest concentrations of organic acids (campaign-average $97.4 \mathrm{ng} \mathrm{m}^{-3}$ ) followed by methane sulfonic, formic, malonic, and malic acids. Samples were also analyzed for glyoxylic, succinic, azelaic and maleic acids. In total, the nine acids composed 1.9 and $3.8 \%$ of $\mathrm{OC}$ and water-soluble $\mathrm{OC}$, respectively (average), in terms of carbon atoms. Levoglucosan concentration varied from 17.7 to $495 \mathrm{ng} \mathrm{m}^{-3}$ with the concentration decreasing in the course of the campaign most likely due to the reduced use of domestic heating with wood. Six factors were found for organic aerosol (OA) at SPC by PMF: hydrocarbon-like OA (HOA), biomass burning OA (BBOA), nitrogen-containing OA (N$\mathrm{OA}$ ) and three different oxygenated OAs (OOA-a, OOA-b and OOA-c). Most of the OA mass was composed of OOAa, HOA and OOA-c (26, 24 and $22 \%$, respectively) followed by OOA-b (13\%), BBOA (8\%) and N-OA (7\%). As expected, OOAs were the most oxygenated factors with organic
\end{abstract}

matter:organic carbon (OM : OC) ratios ranging from 1.9 to 2.2. The diurnal variability of the aerosol chemical composition was greatly affected by the boundary layer meteorology. Specifically, the effect of the nocturnal layer break-up in morning hours was most evident for nitrate and N-OA indicating that these compounds originated mainly from the local sources in the Po Valley. For sulfate and OOA-a the concentration did not change during the break-up suggesting their origin to be mostly regional. That resulted in much more oxidized OA in the daytime mixing layer than in the nocturnal surface layer. In this study, the high mass resolution and source-related aerosol chemistry from the HR-ToF-AMS was combined with the filter measurements in a total new extent elucidating novel features and sources of organic aerosol in the Po Valley region.

\section{Introduction}

The Po Valley is located in the Northern Italy between two mountain ranges, the Alps in the north and west and the Apennines in the south. It is characterized by a high density of anthropogenic emissions and by the frequent occurrence of stagnant meteorological conditions. There are many large industrial, urban and agricultural areas within the Po Valley, resulting in pollution with diverse composition. The area has been identified as one hot spot place where pollutant levels 
remain problematic in spite of the application of the current European legislation devoted to air pollution control. In general, long-range transport represents less than half of the air pollution in the Po Valley region (Sofiev et al., 2011), emphasizing the importance of local control measures in the area to efficiently reduce the impact of air pollution.

Globally, one major air pollution factor is particulate matter. In many locations organic aerosol (OA) makes up a large fraction (20-90\%) of the submicron particulate mass (Sillanpää et al., 2005; Zhang et al., 2007) whereas the rest of the mass consist of soot, inorganic salts, metals and elements. The inorganic and elemental fraction of the particle mass has been characterized well, while much less is known about the composition of the organic fraction. OA is a complex mixture of many classes of organic compounds, which makes tracking of its sources, atmospheric processing, and removal challenging.

OA quantification and chemical composition analysis methods can be divided into two categories: off-line and on-line techniques. Off-line techniques, e.g., gas chromatography/mass spectrometry (GC/MS), liquid chromatography/MS (LC/MS), nuclear magnetic resonance (NMR) and fourier transform infrared (FTIR) spectroscopy, provide detailed information on individual chemical species or functional groups but require large amounts of sample, resulting in low time-resolution (hours to days). On-line techniques (e.g., aerosol mass spectrometry, AMS) usually provide less specific information on the composition, i.e., some level of chemical characterization without details on individual species, but have the advantage of fast acquisition times providing near real-time data.

The measurements and models reveal organic aerosol to be a highly dynamic system, tightly coupled to gas-phase oxidation chemistry (Jimenez et al., 2009). Gas-phase reactions transform OA constituents, and OA itself is an intermediate, often forming from gas-phase precursors and ultimately returning, in part, to gas-phase products. Based on the AMS measurements, OA can be separated into oxygenated OA (OOA), hydrocarbon-like OA (HOA), and sometimes other components such as biomass burning OA (BBOA) in most places. It has been found that the majority of OA mass is OOA which can be further deconvolved into low-volatility OOA (LV-OOA) and semi-volatile OOA (SV-OOA) (Ng et al., 2010). There have been some studies in which only one type of OOA has been observed (Allan et al., 2010; Lanz et al., 2010; Slowik et al., 2010) showing that the split between OOA factors depends not only on chemical heterogeneity but also on the degree of covariance between the factors, and thus on the conditions of the experiment. Increases in OOA are strongly correlated with photochemical activity (Volkamer et al., 2006) and other secondary species (Lanz et al., 2007) indicating that most atmospheric OOA is secondary, formed from either gas-to-particle conversion or oxidized primary OA.
The aim of this study was to characterize the chemistry of submicron particles in the Po Valley region in springtime 2008 using a combination of on-line (mass spectrometric) and off-line analytical methods for organic source identification. The off-line methods were designed for oxygenated organic tracers, providing source information for oxidized organic aerosols in an area affected by both biomass burning and fossil fuel combustion sources. Earlier publications from the Po Valley region have focused on e.g. watersoluble organic compounds (Decesari et al., 2001, Matta et al., 2003), nucleation (Hamed et al., 2007), aerosol composition measurements conducted on airplane (Crosier et al., 2007) and sources of carbonaceous aerosols using a combined ${ }^{14} \mathrm{C}$ - macro tracer analysis (Gilardoni et al., 2011). In this study, the off-line filter measurements for organic acids and biomass burning tracers were combined with the on-line measurement by an Aerodyne high-resolution time-of-flight aerosol mass spectrometer (HR-ToF-AMS). That enabled to (i) explore the sources of organic aerosol in the Po Valley region, (ii) characterize the detailed chemistry of the aerosol in various meteorological conditions and (iii) in different time of the day. This was the first time when high time resolution and source-related aerosol chemistry was examined in the Po Valley region with this extent.

\section{Experimental methods}

\subsection{Measurement site}

The measurements were conducted at the San Pietro Capofiume (SPC) measurement station $\left(44^{\circ} 39^{\prime} 0^{\prime \prime} \mathrm{N}, 11^{\circ} 37^{\prime} 0^{\prime \prime} \mathrm{E}\right.$; Decesari et al., 2001) from 30 March to 20 April 2008. The station is located about $30 \mathrm{~km}$ northeast from the city of Bologna, area open to Adriatic Sea to the east side, but enclosed by densely populated areas on its southern, western and northern sides.

\section{2 $\mathrm{PM}_{1}$ filter measurements}

\subsubsection{Sampling}

$\mathrm{PM}_{1}$ particles were collected using a filter cassette system (Gelman Sciences) similar to that described in Saarikoski et al. (2007). Briefly, four upper stages (8-11) of the Berner low-pressure impactor (BLPI; Berner and Lürzer, 1980) were used prior to the filter cassette at a flow rate of $801 \mathrm{~min}^{-1}$ in order to remove particles with an aerodynamic diameter larger than $1 \mu \mathrm{m}$ from the sample. The nominal cut-off diameter $\left(D_{50}\right)$ for the stage 8 is $2 \mu \mathrm{m}$ with a flow rate of $24.51 \mathrm{~min}^{-1}$. Filter cassette had two quartz filters (Whatman) back-to-back in order to take into account the gas-phase artifacts. The sampling duration for the $\mathrm{PM}_{1}$ was $24 \mathrm{~h}$ with the filter change taking place at 09:00 at local time. The total number of the $\mathrm{PM}_{1}$ samples was 23 . The samples were stored at $-20^{\circ} \mathrm{C}$ prior to the chemical analyses. 


\subsubsection{OC, EC and WSOC analyses}

$\mathrm{PM}_{1}$ filter samples were analyzed for organic carbon (OC) and elemental carbon (EC) by using a thermal-optical carbon analyzer of Sunset Laboratory Inc., Oregon. The temperature program was similar to the method developed by the National Institute for Occupational Safety and Health (NIOSH), except for the last temperature step in the helium phase that was decreased from 850 to $800^{\circ} \mathrm{C}$ (Saarikoski et al., 2007). For the analysis, a $1 \mathrm{~cm}^{2}$ sample piece was punched from the quartz filters. For OC the ratio of back-up filter to front filter ranged from 5.1 to $16 \%$ being on average $8.1 \%$ whereas for EC there were no detectable concentrations on the back-up filter.

Water-soluble organic carbon (WSOC) was analyzed from the $\mathrm{PM}_{1}$ filters with a Total Organic Carbon Analyzer equipped with a high sensitive catalyst (TOC- $\mathrm{V}_{\mathrm{CPH}}$, Shimadzu). For the analysis a $1 \mathrm{~cm}^{2}$ sample piece was punched from the quartz filters. Prior to the WSOC analysis samples were extracted by shaking the filter piece with $15 \mathrm{ml}$ of Milli-Q water for $15 \mathrm{~min}$. TOC method is described in detail in Timonen et al. (2008). Briefly, the method used was the Non-Purgeable Organic Carbon (NPOC) method in which the sample solution is first drawn to syringe where inorganic carbon (carbonates, hydrogen carbonates and dissolved carbon dioxide) is converted to carbon dioxide, and subsequently evaporated from the sample, by adding $\mathrm{HCl}$ $(1 \%)$ to the sample and bubbling it with helium. After that, the sample is injected into an oven, where it is catalytically oxidized to carbon dioxide at $680^{\circ} \mathrm{C}$ and detected by a nondispersive infrared (NDIR) detector. For WSOC the ratio of front-to-back-up filter varied from 2 to $16 \%$ with an average of $7.0 \%$. OC and WSOC concentrations were corrected for blanks by subtracting the concentration on the back-up filter from that on the front filter.

\subsubsection{IC-CD, IC-MS and HPAEC-MS analyses}

Inorganic ions and organic acids were determined from the $\mathrm{PM}_{1}$ filters by using an ion chromatograph (IC) connected to a conductivity detector (CD) and a mass spectrometer (MS). $1 \mathrm{~cm}^{2}$-piece was punched from the quartz fibre filter and extracted into $5.0 \mathrm{ml}$ of deionised water by a short manual shaking followed by $15 \mathrm{~min}$ of gentle rotation. The extract was filtered through an IC Acrodisc ${ }^{\circledR}$ syringe filter $(13 \mathrm{~mm}$, $0.45-\mu \mathrm{m}$ Supor ${ }^{\circledR}$ (PES) membrane, Pall Sciences) that was washed with deionised water freshly prior to the filtering.

Concentrations of major inorganic ions (chloride, nitrate, sulfate, sodium, ammonium, and potassium) were measured using a Dionex ICS-3000 ion chromatography system. Anion analyses were made using a Dionex AG11 guard column $(2 \mathrm{~mm}$ i.d. $\times 50 \mathrm{~mm}$ length $)$ and a Dionex AS11 analytical column ( $2 \mathrm{~mm}$ i.d. $\times 250 \mathrm{~mm}$ length), a 2-mm ASRS-300 suppressor, a CR-ATC anion trap column and a potassium hydroxide $(\mathrm{KOH})$ eluent generator. The eluent flow rate was
$0.3 \mathrm{ml} \mathrm{min}-1$ and the total run time was $13 \mathrm{~min}$. Gradient run was used for the anion analyses $(2-25 \mathrm{mM})$. Cations were analyzed using a CG12A guard column and CS12A analytical column, a 2-mm CSRS-300 suppressor, a CR-CTC cation trap column and methane sulfonate eluent generator. Isocratic run $(23 \mathrm{mM})$ was used for the cation analyses with the flow rate of $0.3 \mathrm{ml} \mathrm{min}^{-1}$ and the total run time of $13 \mathrm{~min}$. The sample loop size was $50 \mu \mathrm{l}$ for both the anion and cation analyses and a conductivity detector was used for the detection of these ions. For the inorganic ions the percentages of back-up to front filters were $4.6( \pm 3.8), 3.3( \pm 3.1), 0.070$ $( \pm 0.081), 1.0( \pm 0.94)$ and $0.35( \pm 0.42) \%$ (average $( \pm$ SD) for chloride, nitrate, sulfate, ammonium and potassium, respectively. For sodium the ratio could not be determined due to its high blank values for the quartz filters.

In order to measure the concentrations of organic acids, the ICS-3000 system was coupled with a quadrupole mass spectrometer (Dionex $\mathrm{MSQ}^{\circledR}$ ). Ionization technique used was electrospray ionization in which the operating parameters were chosen so that the minimum fragmentation and the best sensitivity were achieved. The probe temperature was set to $500^{\circ} \mathrm{C}$, needle voltage to $-3 \mathrm{kV}$, and cone voltage to $-40 \mathrm{~V}$. The molecular ions were monitored using selected ion mode. There are two major advantages of using the mass spectrometer as the detector of the ion chromatograph. First, the use of mass spectrometer as a second detector allows the determination of the concentrations of organic acids which co-elute from the analytical column but can be separated according to their different $\mathrm{m} / \mathrm{z}$ ratios. Second, lower detection limits are achieved for organic acids when they are detected by a mass spectrometer. The percentages of the backup to front filters for the identified organic acids were 9.9 ( \pm 8.8$), 0.33( \pm 1.1), 2.0( \pm 2.5), 2.3( \pm 1.6), 11.7( \pm 13.2)$, $11.3( \pm 9.4), 13.7( \pm 9.4), 0.62( \pm 1.3)$ and $5.3( \pm 11.4) \%$ for formic, methane sulfonic, glyoxylic, oxalic, malonic, maleic, succinic, malic and azelaic acids, respectively. For the rest of the organic acids (acetic, adipic, pinonic and pinic acid) the back-up concentrations were close to their detection limits. Similar to OC and WSOC, inorganic ion and organic acid concentrations were corrected for blanks.

The concentrations of monosaccharide anhydrides (MAs; levoglucosan, mannosan and galactosan) were measured using a high-performance anion-exchange chromatography coupled to electrospray ionization mass spectrometry (HPAEC-MS) modified from the IC-MS system that was used for the organic acids (Dionex ICS-3000 and Dionex $\left.\mathrm{MSQ}^{\circledR}\right)$. The method is described in more detail in Saarnio et al. (2010). The preparation of the $\mathrm{PM}_{1}$ samples for levoglucosan, mannosan and galactosan analyses was similar to that of the ions. Levoglucosan, mannosan and galactosan were not analyzed from the back-up filters because in the previous studies levoglucosan has not been found on the back-up filters (Yttri et al., 2005). 


\subsection{Berner low-pressure impactor}

Size-segregated aerosol samples were collected using a Berner low-pressure impactor (flow rate $4.84 \mathrm{~m}^{3} \mathrm{~h}^{-1}$ ) in which particles were classified into five size fractions according to the following equivalent aerodynamic cut-off diameters at $50 \%$ efficiency: $0.05,0.14,0.42,1.2,3.5$ and $10 \mu \mathrm{m}$. Aluminum and Tedlar foils were used simultaneously as sampling substrates for the determination of total carbon (TC) and of water-soluble components, respectively (Matta et al., 2003). Daytime and night-time samples were collected separately between approximately 08:00 and 20:00 at local time. Consequently, the sampling time of each $\mathrm{PM}_{1}$ filter (Sect. 2.2.1) overlapped approximately with two consecutive BLPI samples.

BLPI samples were analyzed for ions with ion chromatography (Dionex) and WSOC by using an Analytik Jena multiN/C 2100 analyzer. The results are discussed extensively in a companion paper (Paglione et al., 2012), and are used in this study mainly as supporting data for the comparison and validation of the parallel measurements with the $\mathrm{PM}_{1}$ filters and AMS. To this aim, the concentrations determined on each BLPI sample were cumulated over the three finest size ranges (up to $1.2 \mu \mathrm{m}$ of particle diameter).

\subsection{High-resolution time-of-flight aerosol mass spectrometry}

The particle chemical composition was measured by using a high-resolution time-of-flight aerosol mass spectrometer (Aerodyne Research Inc., USA; DeCarlo et al., 2006). The operation of the HR-ToF-AMS is given here only shortly. The AMS has three main sections: an aerosol inlet, particle sizing chamber and particle detection section. The aerosol inlet samples submicron particles into the AMS through an aerodynamic lens forming a narrow particle beam. The beam is transmitted into the detection chamber in which non-refractory components of aerosol are flash vaporized upon impact on hot surface $\left(\sim 600^{\circ} \mathrm{C}\right)$ under high vacuum $\left(\sim 10^{-5} \mathrm{~Pa}\right)$. After that the components are ionized by electron impact ionization and the ions are detected by a mass spectrometer. The transmission of the particle beam to the detector is modulated with a mechanical chopper. The chopper has three positions. An "open" position transmits the beam continuously, "closed" position blocks the beam completely, and "chopped" position modulates the beam transmission with a $1-4 \%$ duty cycle which is determined by the width of the slit in chopper (Jayne et al., 2000).

AMS alternates between two modes of operation: mass spectrum (MS) and particle-Time-of-Flight (PToF) mode. In the MS mode the chopper is in open position to obtain an ensemble-average MS of the sampled air. Signal from the background gases is accounted for by subtracting the MS obtained with the chopper in closed position. The particle size is determined in the PToF mode. When the chopper is oper- ating in the chopped mode, the particle velocity is measured from its flight time between a chopper and the vaporizer surface. The HR-ToF-AMS has ion optics for two modes of operation: V-and $\mathrm{W}$-mode. In the V-mode ions follow the traditional reflection path whereas in the $\mathrm{W}$-mode the ions exiting the reflector are directed into a hard mirror that focuses them back into the reflector for a second time before travelling to a multichannel plate detector. The mass resolving power of the ToF-MS increases as the flight path is lengthened but the lateral broadening of the ions increases over a longer flight path and reduces the total signal as fewer ions struck the detector. Therefore the V-mode is more sensitive but the W-mode offers higher mass resolution. The resolutions for the V-mode and W-mode are typically $\sim 2000$ and 4000, respectively (DeCarlo et al., 2006). In this study the time-resolution for the AMS was set to $5 \mathrm{~min}$ as one single measurement consists of 2.5 min of $\mathrm{V}$-mode and $2.5 \mathrm{~min}$ of $\mathrm{W}$-mode measurements. PTof was measured only in the Vmode ( $2 / 3$ of time).

\subsubsection{Collection efficiency}

In general a constant collection efficiency (CE) of 0.5 is applied to the AMS data (e.g. Allan et al., 2004; Sun et al., 2009; Canagaratna et al., 2007). However, CE can also be a function of particle phase and chemical composition (Allan et al., 2004; Huffman et al., 2005; Crosier et al., 2007; Matthew et al., 2008; Takegawa et al., 2009; Middlebrook et al., 2012). Aerosol particles sampled from inlets with high relative humidity and particles with high ammonium nitrate or acid content, for example, have CE values approaching 1 . In general, for nitrate fraction $<0.25$ a CE of 0.5 is used whereas for fraction $>0.25 \mathrm{CE}$ increases linearly to 1 . In this study the observed aerosol was neutralized (Supplement Fig. S1) and the nitrate mass fraction ranged from 0.06 to 0.58 with an average of 0.31 .

A collection efficiency of 0.5 was applied for the whole data set as a first guess. With a CE of 0.5 , a comparison between the total mass from the AMS (sum of organics, nitrate, sulfate, ammonium and chloride), that from the $\mathrm{PM}_{1}$ (sum of $\mathrm{OC} \times 1.77$; the factor will be calculated in Sect. 3.2.2, nitrate, sulfate, ammonium, chloride) and corresponding size fraction of the BLPI measurements (sum of WSOC $\times 1.8$; Docherty et al., 2008, nitrate, sulfate, ammonium, chloride) is shown in Fig. S2 together with the comparison of AMS to $\mathrm{BLPI} / \mathrm{PM}_{1}$ for nitrate, organics, sulfate and ammonium. In general, the ratio of AMS-to-BLPI was higher than that of AMS-to-PM $\mathrm{P}_{1}$ but both the ratios changed during the campaign. AMS mass concentrations calculated with a $\mathrm{CE}=0.5$ value reproduced both the BLPI and $\mathrm{PM}_{1}$ during the latter portion of the campaign, but showed a systematic underprediction for the aerosol mass concentrations measured by both the instruments during the first weeks of the campaign. Since both instrument intercomparisons showed this underprediction, the AMS mass concentrations calculated with a 
$\mathrm{CE}=0.5$ from the beginning of the campaign until 9 April, 11:33 (LT) were increased by multiplying them by an additional factor of 1.67. However, the exact reason for this under-prediction is not clear. The under-prediction in absolute AMS mass concentrations does not clearly correlate with any changes in the aerosol composition but concerning the meteorology relative humidity was slightly lower from the beginning of the campaign to midday on 9 April (average RH $64 \%$ ) than after that until the end of the campaign (average RH $76 \%$ ). It is also useful to note that the deviations between the AMS and $\mathrm{PM}_{1}$ or BLPI for individual $12 \mathrm{~h}$ (BLPI) or $24 \mathrm{~h}\left(\mathrm{PM}_{1}\right)$ periods include uncertainties in the estimated filter mass. For example, the conversion used to calculate organic matter may be higher or lower than the used value of 1.77 (or 1.8 for WSOC).

Supplement Table S1 shows a summary of the intercomparison between the AMS mass concentrations (calculated with a $\mathrm{CE}=0.5$ and corrected for apparent systematic bias before 9 April, 11:33) and the $\mathrm{PM}_{1}$ and BLPI based mass concentrations. For nitrate the AMS gave slightly higher concentrations than the BLPI $(2 \%)$ or the $\mathrm{PM}_{1}(16 \%)$ whereas for ammonium the concentrations obtained from the AMS were higher than those from the BLPI (3\%) but lower than from the $\mathrm{PM}_{1}(8 \%)$. Sulfate from the AMS was considerably lower than that from the BLPI $(64 \%)$ or $\mathrm{PM}_{1}(51 \%)$ but the reason for the low sulfate concentrations measured by the AMS couldn't be found. However, one explanation could be that the vaporizer temperature was actually slightly lower than indicated by the thermo-couple temperature measurement $\left(600^{\circ} \mathrm{C}\right)$. This would have an effect on less-volatile sulfate but not affecting semi-volatiles like ammonium nitrate or most of organics. Organics from the AMS were compared either with WSOC from the BLPI or OC from the $\mathrm{PM}_{1}$ filters. Organics had 2.22 times higher concentrations than WSOC from the BLPI, which makes sense since AMS organics include also water-insoluble organic carbon as well as other atoms than carbon (hydrogen, oxygen, nitrogen, sulfur). The ratio of AMS organics to $\mathrm{OC}$ from the $\mathrm{PM}_{1}$ filters was 1.49 on average. The ratio of organic matter to organic carbon at SPC will be discussed later in this paper. The concentrations of the chemical species from the AMS agreed well with those from the $\mathrm{PM}_{1}$ or BLPI samples $(R=0.83-0.94)$ except sulfate $(R=0.69$ for AMS vs. BLPI).

\subsubsection{Data analysis}

All data was analyzed using a standard AMS data analysis software (SQUIRREL v1.49 and PIKA v.1.08B; Sueper, 2008) within Igor Pro 6 (Wavemetrics, Lake Oswego, OR). Positive matrix factorization (PMF, Paatero and Tapper, 1994; Lanz et al., 2007; Ulbrich et al., 2009) was conducted on high-resolution mass spectra of organics (W-mode) with $m / z$ below 100 .

PMF was applied to the high-resolution mass spectra of $\mathrm{OA}$ by varying the number of factors from three to ten. The plot of $Q / Q_{\text {exp }}$ vs. number of factors (nF, $n=3-10$ ) shows that when the number of factors was increased $Q / Q_{\exp }$ decreased (Fig. S3). PMF solutions from 5F to 7F (MS and time series) are shown in Supplement (Fig. S4). Of those, 6Fsolution seemed to be the most reasonable. In $6 \mathrm{~F}$-solution the organic aerosol components were identified as HOA, BBOA, three OOAs (OOA-a, OOA-b and OOA-c) and nitrogencontaining $\mathrm{OA}(\mathrm{N}-\mathrm{OA})$. The factors were identified according to their MS signatures, diurnal cycles and the correlation of their time series with other aerosol chemical components.

Compared to $6 \mathrm{~F}$-solution, in $4 \mathrm{~F}$-solution BBOA could not be separated from the other factors as $m / z 60.021\left(\mathrm{C}_{2} \mathrm{H}_{4} \mathrm{O}_{2}^{+}\right)$ and $73.029\left(\mathrm{C}_{3} \mathrm{H}_{5} \mathrm{O}_{2}^{+}\right)$, which are known to be tracers for BBOA, were included in HOA. Starting from 5F-solution, there was a separate factor for BBOA that had the biomass burning-related $m / z$ 's (60.021 and 73.029), however, in 5Fsolution BBOA did not correlate with levoglucosan $(R=$ 0.39) (or mannosan or galactosan) from the $\mathrm{PM}_{1}$ filter samples (Fig. S5b). In 6F- and 7F-solutions BBOA agreed well with levoglucosan $(R=0.81$ and 0.84 , respectively). Similarly to levoglucosan the correlation between BBOA and WSOC, EC, K and most of the organic acids, analyzed from the $\mathrm{PM}_{1}$ filters, increased going from $5 \mathrm{~F}$ - to $6 \mathrm{~F}$-solution. These correlations were even slightly better in 7F-solution.

The other factors did not change as much as BBOA when the number of factors changed. The contributions of HOA and OOA-a to total OA decreased slightly going from 4F-solution to 7F-solution as the new factors were added (Fig. S6a). The correlation between HOA and levoglucosan decreased when the number of factors increased whereas the correlation of $\mathrm{HOA}$ with nitrogen oxides $\left(\mathrm{NO}_{\mathrm{x}}, \mathrm{NO}_{2}\right.$ and NO) increased until $6 \mathrm{~F}$ after which it collapsed (Fig. S5a). OOA-c had little higher contributions in $4 \mathrm{~F}$ - and $7 \mathrm{~F}-$ than in $5 \mathrm{~F}$ - and $6 \mathrm{~F}$-solutions. N-OA lost some mass from going from $4 \mathrm{~F}$ to $6 \mathrm{~F}$-solution but its contribution increased again in $7 \mathrm{~F}$-solution. Compared to $6 \mathrm{~F}$-solution, in $6 \mathrm{~F}$-solution there was an additional OOA-factor (OOA-b in Fig. S4b) that had MS resembling the two other OOAs (especially OOA-a) with a lot of oxygenated fragments that were shifted from both BBOA and N-OA. However, the time series and diurnal trend of OOA-b were different from OOA-a and OOA-c. In 7Fsolution the additional factor (Factor 6 in Fig. S4c) had similar time series with N-OA and its MS had signal from various nitrogen-containing compounds (Figs. S4c and S6b; additional factor labeled as N-OAx in Figs. S5-S6). That additional N-OAx factor had very low contribution to the total mass (3.5\% on average; Fig. S6a).

OOA-a and OOC-c were slightly more oxidized when the number of factors increased whereas OOA-b had lower $\mathrm{O}: \mathrm{C}$ ratio in $7 \mathrm{~F}$ - than in $6 \mathrm{~F}$-solution (Fig. S6b). The ratio of $\mathrm{H}: \mathrm{C}$ increased for HOA going from 4F- to 7F-solution. Even though the correlations between PMF factors and $\mathrm{PM}_{1}$ filters were slightly better in $7 \mathrm{~F}$-solution compared to that of $6 \mathrm{~F}$-solution, the difference was rather small. Also the seventh 
factor (N-OAx in Fig. S5-S6) seemed to be quite unimportant since its contribution was low and the resemblance to $\mathrm{N}$ OA was large (especially in time series and diurnal trends). Thus, 6F-solution was selected for further analysis.

f-Peak values were tested to explore the possibility of local minima in the Q-space. The value for the f-Peak (Fig. S7) was chosen to be 0 . f-Peak had slightly lower $Q / Q_{\text {exp }}$ values for $-0.4,-0.2$ and 0.2 than for 0 but the difference was small. However, there was a significant difference in the comparison of BBOA to levoglucosan for different values of $\mathrm{f}$ Peaks. For the f-Peak value of 0 the correlation coefficient $(R)$ was 0.813 (Table S2) whereas for f-Peak of -0.2 and 0.2 the coefficients were 0.412 and 0.336 , respectively. Bootstrapping was used to evaluate the statistical uncertainty of 6F-solution. The results from the bootstrapping analysis for MS and time series are shown in Fig. S8. The minimum error value for the error matrix was calculated as the average noise value observed for ions during low signal time periods (Huang et al., 2010).

\subsection{Auxiliary data}

Micro-meteorological parameters were monitored with a WXT510 (Vaisala) station. Gaseous ammonia concentrations were measured on-line using an automatic denuderbased system (AMANDA, ECN) while time-resolved concentrations of $\mathrm{NO}, \mathrm{NO}_{\mathrm{x}}$ and ozone were furnished by the Emilia-Romagna monitoring network for atmospheric pollution. $\mathrm{SO}_{2}$ was measured by using a Monitor Labs model 8850. LD-40 lidar-ceilometer (Vaisala, Finland) was operated in elastic backscatter at the wavelength of $855 \mathrm{~nm}$ to study the aerosol vertical distribution in the first $4000 \mathrm{~m}$ above ground level. Signal profiles are averaged every $15 \mathrm{~min}$ and have a vertical resolution of $7.5 \mathrm{~m}$. Minima in the first derivative of the intensity of the signal were used to identify aerosol stratifications, including the top of the mixing layer or of the nocturnal stable surface layer.

\section{Results and discussion}

\subsection{General description of the measurement campaign}

Meteorological conditions during the campaign are presented in Fig. 1. Temperature and wind speed had clear diurnal cycles with higher values observed during the daytime. Relative humidity had peak values in the night. During the campaign temperature varied from 3 to $21^{\circ} \mathrm{C}$ with the campaign-average of $12.2^{\circ} \mathrm{C}$. Relative humidity was in the range of $28-98 \%$ averaging at $70.1 \%$. There were some showers during the campaign, especially on the second half of the campaign. Wind speed varied from 0.5 to $8.7 \mathrm{~m} \mathrm{~s}^{-1}$ with an average of $2.9 \mathrm{~m} \mathrm{~s}^{-1}$ but wind direction had not emphasis on any particular sector.

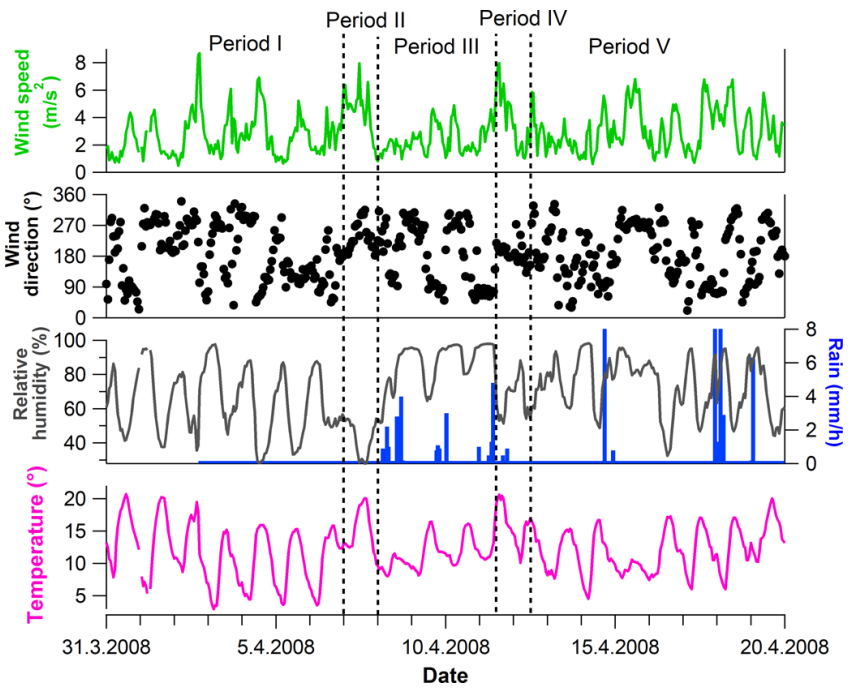

Fig. 1. Meteorological parameters (wind speed, wind direction, relative humidity, precipitation and temperature) at SPC during the campaign.

The concentrations of inorganic gases are shown in Fig. S9. At the beginning of the campaign (until 5 April) the concentrations of $\mathrm{NO}_{\mathrm{x}}, \mathrm{NO}$ and $\mathrm{NO}_{2}$ were significantly higher than during the rest of the campaign. For the other gases same kind of time trend could not be observed even though for $\mathrm{SO}_{2}$ there were several periods when the concentrations increased considerably.

In general the measurement campaign can be divided into five distinct time periods. During the first period (Period I), from 30 March to 6 April, the pollutant levels were quite high and there were clear diurnal cycles in the aerosol concentration and composition. According to the backward trajectories (HYSPLIT) air masses came to SPC mostly from the northeast or north. The second period (Period II), 7 April, was characterized by low background conditions and a significant transport from outside of the Po Valley. Air masses arrived in SPC from south-west, from Mediterranean. The third period (Period III), from 8 April to noon on 11 April, had the highest concentrations levels observed during the campaign with only a little diurnal variation. According to the trajectories air masses came from south and south-west during Period III. The fourth period (Period IV), from noon 11 to noon 12 April, was the second background period. Similar to the first background period the air masses came from the Mediterranean. The fifth period (Period V) was from noon 12 April to the end of the campaign, and it was characterized by the high variability in the concentrations and intermittent scavenging. During Period V the air masses arrived in SPC from south-west sector. 


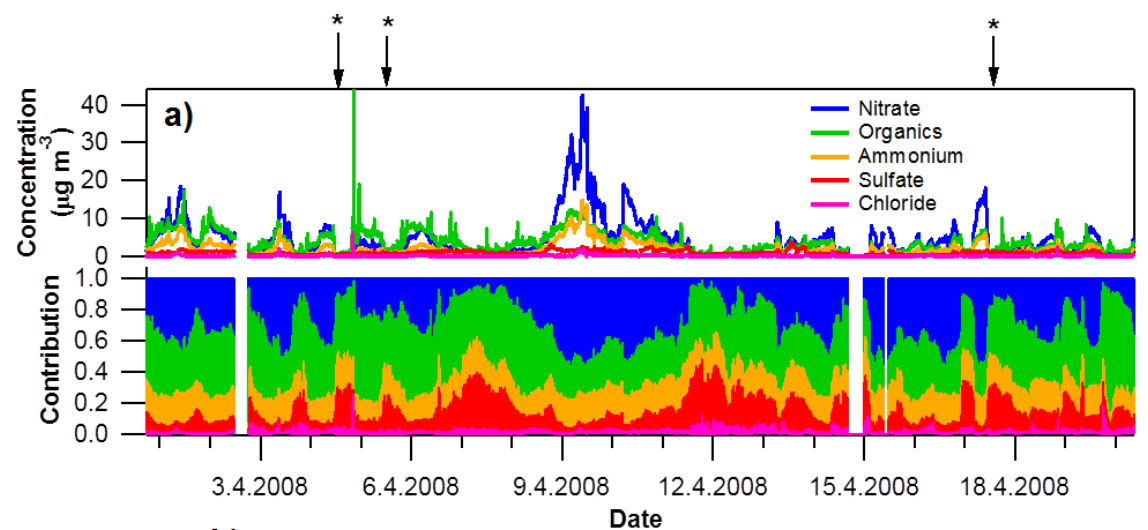

b) Date
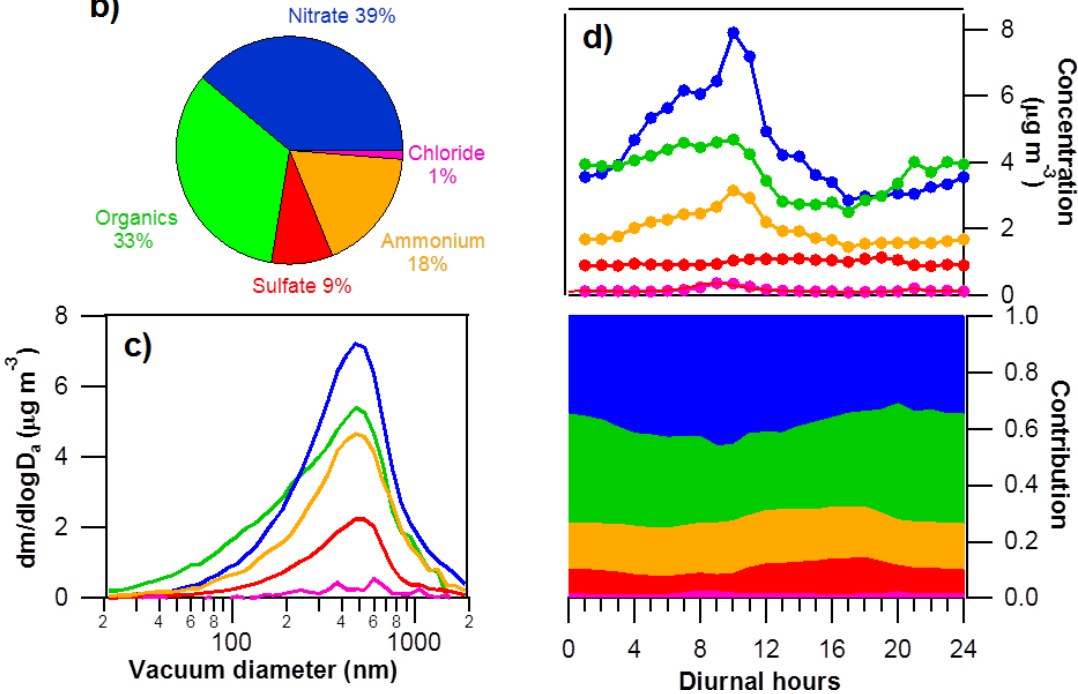

Fig. 2. Time series (a), average chemical composition (b), size-distribution (c) and diurnal variation (d) of HR-ToF-AMS species at SPC. In (b) and (d) the data was averaged over the whole campaign, from 31 March to 21 April, and in (c) from 9 April to 21 April 2008. Asterisks and arrows in (a) present the cases with the nocturnal surface layer break-up discussed in Sect. 3.4. Note that sulfate concentrations from the HR-ToF-AMS were much smaller than those from the BLPI or $\mathrm{PM}_{1}$ filter measurements probably due to the instrumental issues. See details in Sect. 2.4.1.

\subsection{Chemical composition of fine particles}

\subsubsection{Non-refractory species from the HR-ToF-AMS}

Fine particles at SPC were mostly composed of nitrate followed by organics (Fig. 2). For nitrate the concentrations ranged from 0.03 to $43.7 \mu \mathrm{g} \mathrm{m}^{-3}$ whereas the concentrations of organics varied from 0.2 to $42.8 \mu \mathrm{g} \mathrm{m}^{-3}$ (15 min averages). Nitrate concentration was at its highest between 9 and 11 April (Period III). During that time also the ammonium and organics concentrations were elevated. The highest organics concentrations $\left(42.8 \mathrm{\mu g} \mathrm{m}^{-3}\right)$ were measured in the late night on 4 April (Period I), however, none of the other species measured by the HR-ToF-AMS increased at the same time. The peak concentration of organics was most likely caused by a vehicle bypassing the site indicated by a high signal at $\mathrm{m} / z 55$ and 57 (Canagaratna et al., 2004). The campaignaverage concentrations for organics, nitrate, ammonium, sul- fate and chloride were $3.8 \pm 2.7,4.4 \pm 5.3,1.9 \pm 1.8,0.9 \pm 0.5$, and $0.14 \pm 0.2 \mu \mathrm{g} \mathrm{m}^{-3}$, respectively. The measured ammonium concentrations matched with ammonium required to fully neutralize sulfate, nitrate and chloride with a linear correlation coefficient $(R)$ of 0.99 and a slope of 0.88 (Fig. S1).

On average, $39 \%$ of the particle mass was made of nitrate, $33 \%$ of organics, $18 \%$ of ammonium, $9 \%$ of sulfate and $1 \%$ of chloride (Fig. 2b). The mass contributions of sulfate and nitrate varied during the campaign in contrast to the contributions of organics, ammonium and chloride that were more steady (Fig. 2a). In general, the contribution of sulfate was larger when the absolute concentrations were low whereas the large relative contributions of nitrate corresponded to large absolute concentrations of nitrate.

The campaign-average diurnal trends for organics, nitrate, sulfate, ammonium and chloride are presented in Fig. 2d. Largest diurnal variation was observed for nitrate. Nitrate had clearly higher concentrations from early morning 
$(\sim 04: 00)$ to noon $(\sim 12: 00)$ peaking at 10:00. After 10:00 the concentrations started to decrease due to the transfer of ammonium nitrate from particles to gas-phase and the development of mixing layer. The early morning increase can be explained by the local sources of nitrate precursors (traffic) and the poor mixing of pollutants in nighttime. The diurnal trend for ammonium followed closely that of nitrate. The concentration of organics was quite stable in the night and early morning but it decreased $\sim 10: 00$ and stayed at a lower level until the evening ( 20:00) reflecting the change in the boundary layer height and the mixing of pollutants but also the evaporation of semivolatile components due to the higher ambient temperature. The formation of secondary organic aerosol (SOA), that would have peaked in the afternoon (Zhang et al., 2005; Plaza et al., 2006; Takegawa et al., 2006), was not observed in the concentration of organics. However, regarding the elemental composition of organics (Sects. 3.2.2 and 3.4) the formation of SOA could be speculated. Regarding sulfate the diurnal trend was almost the opposite of organics. The concentration of sulfate increased slightly in the afternoon, which suggests that the origin of sulfate was mostly regional since its concentration increased when the mixing layer was developed. Moreover, ammonium sulfate is a non-volatile component meaning that there is not significant evaporation from particles to gas-phase with higher temperatures in the afternoon. For chloride there was a peak in the morning $(\sim 06: 00-12: 00)$ that coincided with the trend of ammonium suggesting that chloride might be in the form of ammonium chloride. Even though all the species had a diurnal trend, their diurnal mass contributions were fairly steady throughout the day (Fig. 2d). For the nitrate mass contribution the diurnal pattern followed that of the concentration with slightly larger contributions from 04:00 to 14:00 whereas the contribution of organics had just the opposite trend. The mass contribution of sulfate was highest in the afternoon. The effect of nocturnal surface layer breakup on particle chemical composition will be discussed more detailed in Sect. 3.4.

The average mass size-distributions from 9 to 20 April are shown in Fig. 2c for organics, nitrate, sulfate, ammonium and chloride. There was no size-distribution data before 9 April because of the incorrect chopper parameters of PToF. The shape of the size-distributions was very similar for nitrate, sulfate and ammonium suggesting that they were internally mixed. On average, they all had an accumulation mode peaking at the size of $500 \mathrm{~nm}$, but besides that, there was an additional mode peaking at $\sim 100 \mathrm{~nm}$ being either large Aitken or small accumulation mode. Similar to inorganics, organics had also an accumulation mode at $500 \mathrm{~nm}$, however, organics had more particulate mass at the size range of $30-350 \mathrm{~nm}$ compared to the peak of the mode. Obviously, the size distribution of organics is multi-modal and besides the dominant accumulation mode at $500 \mathrm{~nm}$ it probably has two additional modes; second accumulation mode at $\sim 200 \mathrm{~nm}$ and an Aitken mode below $100 \mathrm{~nm}$. Broader distribution for organ- ics has been found previously for both the urban and rural locations (Alfarra et al., 2004; Zhang et al., 2005, Allan et al., 2006; Huang et al., 2010). Time evolution for the sizedistributions revealed that the distributions did not change much during the campaign (not shown), however, the concentration level had a slight effect on the size-distribution. When the concentrations were very low (Periods II and IV), nitrate, ammonium and organics peaked at $550 \mathrm{~nm}$ but the peak shifted to $500 \mathrm{~nm}$ when the concentrations increased (especially in Period III). For sulfate the shift could not be seen as its concentration level was quite stable throughout the campaign. For chloride the concentrations were too low for the proper size distribution measurements.

\subsubsection{Elemental composition}

High resolution mass spectra obtained in this study enabled the investigation of the molecular ratios of $\mathrm{O}, \mathrm{C}, \mathrm{H}, \mathrm{N}$ and $\mathrm{S}$ in organic aerosol. $\mathrm{O}: \mathrm{C}$ ratio varied from 0.25 to 0.75 with an average of 0.47 (Fig. 3a). It had a clear diurnal variation with the smallest ratio in the morning (08:00-10:00) and the largest ratio in the afternoon (13:00-17:00; Fig. 3b). Higher $\mathrm{O}: \mathrm{C}$ ratios in the afternoon can be explained by several factors. Increased contribution of oxygen in OA can result from the oxidation of OA (SOA formation) in the afternoon but also from the mixing of nocturnal surface layer aerosol with the aerosol aloft, that is more oxidized, with the mixing layer development. That will be discussed later with the PMF factors and in Sect. 3.4. The campaign-average $\mathrm{H}: \mathrm{C}$ ratio was 1.49. For $\mathrm{H}: \mathrm{C}$ ratio the diurnal trend was just the opposite of $\mathrm{O}: \mathrm{C}$ ratios having the largest ratio in the morning (08:0010:00) and smallest in the afternoon (14:00-17:00).

Only few sulfur-containing organic compounds were detected at SPC (e.g. MSA, Sect. 3.3) resulting in a very low campaign-average $\mathrm{S}: \mathrm{C}$ ratio (0.0014). However, there was a notable amount of nitrogen-containing organic compounds $\left(\mathrm{C}_{\mathrm{x}} \mathrm{H}_{\mathrm{y}} \mathrm{N}\right)$ and therefore a clear $\mathrm{N}: \mathrm{C}$ ratio for $\mathrm{OA}$. The highest $\mathrm{N}: \mathrm{C}$ ratios observed were $\sim 0.04$. The diurnal trend for the $\mathrm{N}: \mathrm{C}$ ratio followed roughly the trend of $\mathrm{H}: \mathrm{C}$ (Fig. 3b) and nitrate (Fig. 2d) with the morning maximum. That suggests the nitrogen-containing compounds to be related to vehicle traffic but the morning peak can also originate from a continuous accumulation of aerosol in the nocturnal surface layer, followed by their dispersion once the mixing layer develops. In this case, the $\mathrm{N}$-containing compounds could come from any sources at the ground, including the emission from soil, or from livestocks, etc. Compared to the $\mathrm{H}: \mathrm{C}$ ratio, $\mathrm{N}$ : $\mathrm{C}$ ratio did not decrease steeply after the morning maximum, it rather decreased slowly towards the night minimum. On average, the ratio of $\mathrm{N}: \mathrm{C}$ was 0.018 . Nitrogen-containing organic compounds will be discussed later in this paper.

The organic mass: organic carbon $(\mathrm{OM}: \mathrm{OC})$ ratio varied from 1.4 to 2.1 during the campaign with an average of 1.77 (Fig. 3a). It had a similar diurnal pattern to that of $\mathrm{O}: \mathrm{C}$ in line with the previous results that showed the $\mathrm{O}: \mathrm{C}$ 


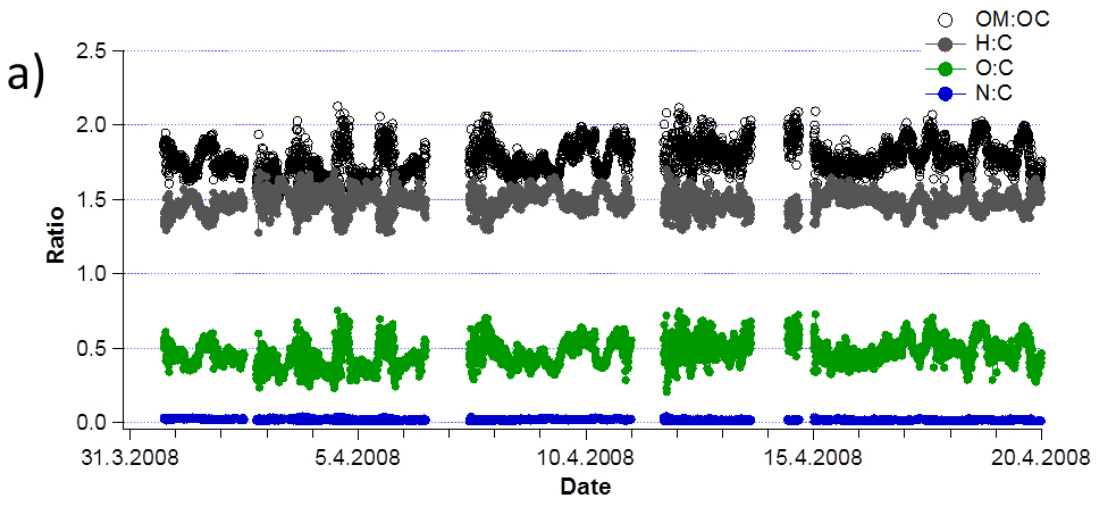

b)

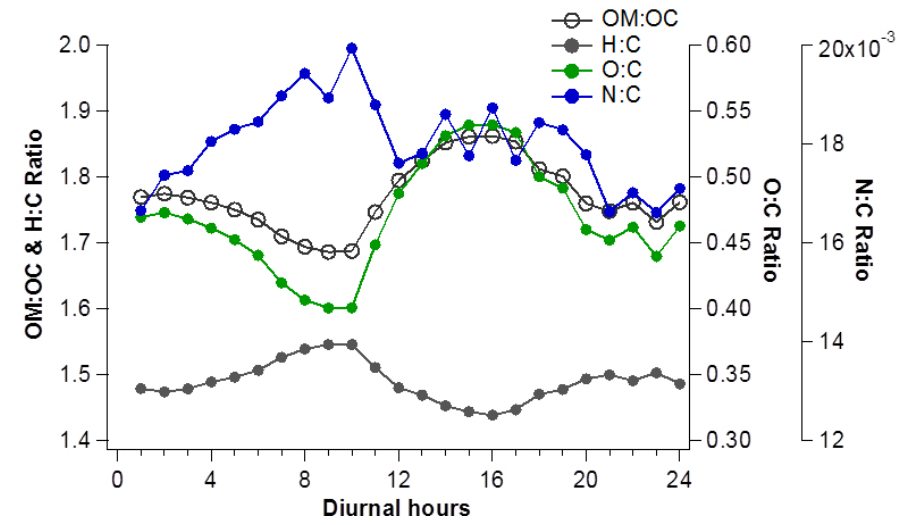

Fig. 3. Elemental analysis of HR-ToF-AMS-data. Time series for OM:OC, H:C, O:C and N:C ratios (a) and their average diurnal trends (b).

ratio being the term that governs the $\mathrm{OM}$ : $\mathrm{OC}$ ratio (Pang et al., 2006). The concentration of organics was divided by the $\mathrm{OM}$ : $\mathrm{OC}$ ratio in order to get the concentration of $\mathrm{OC}$ from the HR-ToF-AMS. That HR-ToF-AMS OC was compared to the OC concentrations obtained by analyzing the 24-h $\mathrm{PM}_{1}$ filters by thermal-optical method in the laboratory (Fig. 4). The two measurements of OC agreed well $(R=0.926)$ with the HR-ToF-AMS giving $14 \%$ lower values. That could be due to several things i.e. the gas-phase artifacts in the filter sampling or the collection efficiency applied for the HR-ToFAMS data.

\subsubsection{Organic acids from the $\mathrm{PM}_{1}$ samples}

Organic acids were analyzed from the 24-h $\mathrm{PM}_{1}$ filter samples. The highest concentrations were measured for oxalic acid with an average of $97.4 \mathrm{ng} \mathrm{m}^{-3}$ during the campaign (Fig. 5). Oxalic acid comprised roughly half of the total amount of all organic acids determined. The concentrations of formic, malonic and malic acid were much lower than those of oxalic acid but on average they were higher than those of glyoxylic, succinic and azelaic acids. Maleic acid concentrations were barely above the detection limit in many samples. Methane sulfonic acid had smaller concentrations than oxalic acid but larger concentrations than the

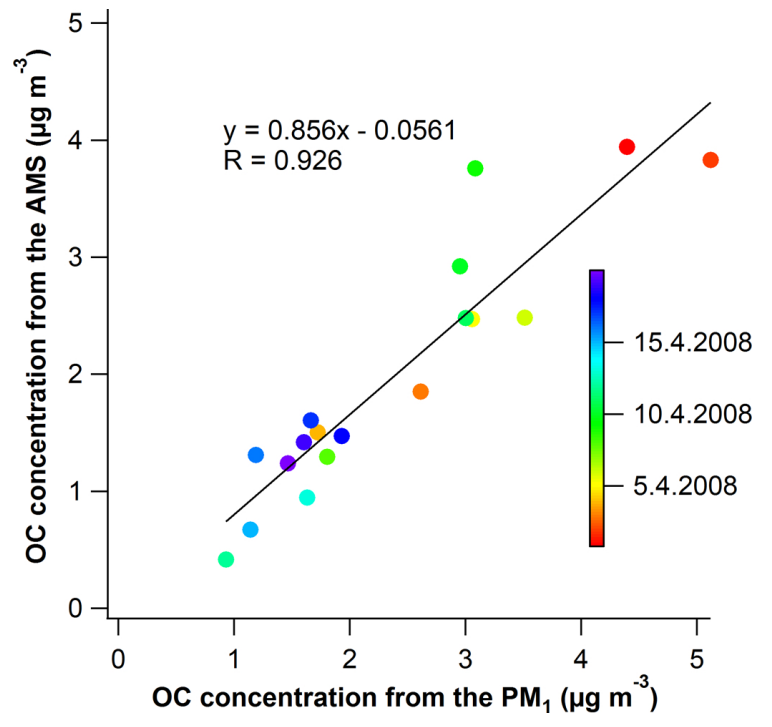

Fig. 4. Carbon from the HR-ToF-AMS vs. OC from the $\mathrm{PM}_{1}$ filter sampling. Markers are colored by the dates with the color scale ranging from 1 to 19 April 2008. 


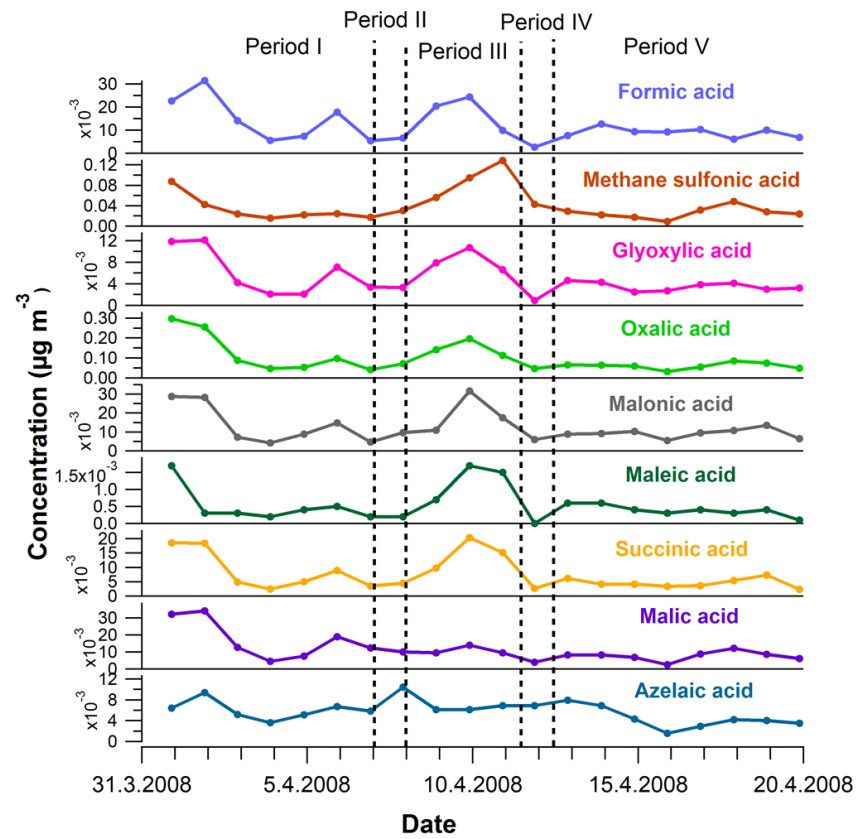

Fig. 5. The concentrations of formic, methane sulfonic, glyoxylic, oxalic, malonic, maleic, succinic, malic and azelaic acids from 28 March to 20 April 2008 analyzed from the 24-h PM $_{1}$ samples.

other acids its campaign-average concentration being equal to $38.7 \mathrm{ng} \mathrm{m}^{-3}$. Individually organic acids comprised from 0.0091 to $0.97 \%$ of OC and from 0.018 to $1.9 \%$ of WSOC in terms of carbon atoms. In total, the nine acids composed 1.9 and $3.8 \%$ of OC and WSOC, respectively (campaignaverage).

Oxalic, malonic and succinic acid concentrations at SPC were at the same level with those measured previously in Puy de Dôme, France but the concentration of glyoxylic acid was much larger at SPC than at any of the seven European sites participating the CARBOSOL project (Legrand et al., 2007). Also the concentrations of formic and malic acids were much larger at SPC than those measured earlier in Zurich, however, in the same Zurich study the concentration of maleic acid was close to that measured at SPC (Fisseha et al., 2006).

The daily variation of formic, glyoxylic, oxalic, malonic and succinic acids was remarkably similar (Fig. 5). They all have the highest concentrations in the first two samples (31 March-1 April and 1-2 April) and in the second polluted period (Period III). Their concentrations compared well with each other (Pearson $R=0.76-0.94$ ), which suggests that these acids were either primarily emitted (or fast secondarily produced) together or formation processes of these acids were somehow related. However, since they also had similar trends with inorganic compounds, nitrate, sulfate, ammonium, and potassium, as well as with $\mathrm{OC}$ analyzed from the $\mathrm{PM}_{1}$ filters, it seems that more than indicating similar sources/atmospheric processing the correlations displayed the difference between polluted air masses coming from the urban areas in the Po Valley and the cleaner air masses coming from the Mediterranean. Malic acid had somewhat similar time evolution with formic, glyoxylic, oxalic, malonic and succinic acids (Fig. 5). Its concentration was the highest for the first two samples, however, during the second polluted period malic acid did not increase noticeably.

Maleic acid had slightly different behavior from formic, glyoxylic, oxalic, malonic, succinic and malic acids. It also had the highest concentrations in the first sample (31 March1 April) and Period III but it compared weaker with other acids ( $R=0.18-0.77)$ as well as inorganic components, OC and $\mathrm{EC}$ in the $\mathrm{PM}_{1}$ filters. In addition to different sources and/or formation processes weak correlation could be due to the high uncertainty associated with its concentrations during the clean period. Also the time evolution of azelaic acid was different from the other organic acids since its concentrations did not increase during the polluted period (Period III). Actually, the highest concentration of azelaic acid was detected on 7-8 April that was a background period (Period II) when none of the other aerosol components analyzed had elevated concentrations. Azelaic acid is formed from unsaturated fatty acids, e.g. oleic acid, by oxidation. These unsaturated acids are found in marine phytoplankton and terrestrial higher plant leaves but they are also emitted by anthropogenic sources such as meat cooking (Rogge et al., 1991) and wood burning processes (Rogge et al., 1998). Methane sulfonic acid agreed moderately with the other acids, however, it compared well with $\mathrm{PM}_{1}$ filter chloride since it is most likely an oxidation product of dimethyl sulfide (DMS) which is produced by ocean phytoplankton (Seinfeld and Pandis, 1998).

Kawamura and Ikushima (1993) proposed that malonic acid is produced by photochemical oxidation of succinic acid in the atmosphere, and hence malonic-to-succinic acid ratio has been used as an indicator of enhanced photochemical production of diacids (Kawamura et al., 1996; Pavuluri at al., 2010). At SPC the average ratio of malonic-to-succinic acid was 1.74 ranging from 0.83 (first sample) to 2.83 (last sample). In general, the trend was that the ratio increased as the spring progressed.

\subsubsection{Biomass burning tracers from the $\mathrm{PM}_{1}$ samples}

Three monosaccharide anhydrides, levoglucosan, mannosan and galactosan, were analyzed from the $\mathrm{PM}_{1}$ filter samples. They are all produced exclusively during the pyrolysis of cellulose and hemicellulose, which makes them specific atmospheric tracers for biomass combustion emissions (Simoneit et al., 1999; Nolte et al., 2001).

The concentration of levoglucosan varied from 17.7 to $495 \mathrm{ng} \mathrm{m}^{-3}$ during the campaign with the highest concentrations observed in the first sample (31 March-1 April) and the sixth sample (5-6 April; Fig. 6). In general, the concentration decreased in the course of the campaign. That was most likely due to the reduced use of domestic heating with 


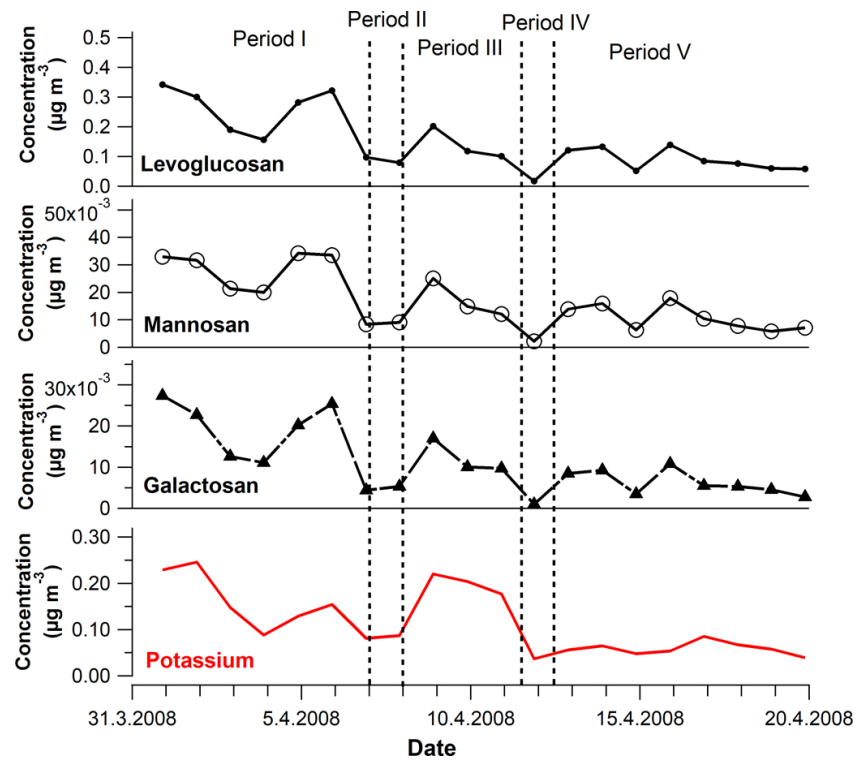

Fig. 6. The concentration of levoglucosan, mannosan, galactosan and potassium from 28 March to 20 April 2008 analyzed from the 24-h $\mathrm{PM}_{1}$ samples.

wood due to slightly higher night temperatures, although the daily-averaged ambient temperature was rather stable during the campaign (Fig. 1). The lifetime of levoglucosan can be prone to hydroxyl radical exposure (Hennigan et al., 2010) but the degradation of levoglucosan was not assumed to be the reason for the decreased concentrations as the intensity of the solar radiation did not show any trend in the course of the campaign.

The campaign-average concentration of levoglucosan was $176 \mathrm{ng} \mathrm{m}^{-3}$ that corresponded to $2.7 \%$ of $\mathrm{OC}$ and $4.1 \%$ of WSOC in terms of carbon atoms. Those were in the range of values obtained earlier in Europe (Saarikoski et al., 2008). The concentrations of mannosan and galactosan were much smaller than that of levoglucosan having the campaignaverages of 19.3 and $12.8 \mathrm{ng} \mathrm{m}^{-3}$, respectively. The concentrations of the three biomass tracers followed each other closely (Fig. 6) with the proportions of $84.4( \pm 1.34), 9.56$ $( \pm 0.92)$ and $6.0( \pm 0.90) \%$ for levoglucosan, mannosan and galactosan, respectively (average \pm std). These proportions were close to those measured in Helsinki, Finland (Saarnio et al., 2010) but somewhat different from those detected in Norway (Yttri et al., 2005). In Norway the proportions of levoglucosan and galactosan were lower whereas that of mannosan was more than twice that measured at SPC. The agreement between the three tracers was strong $(R=0.98-0.99)$ but they also compared well with OC $(R=0.82-0.87)$ and EC $(R=0.76-0.79)$ analyzed from the $\mathrm{PM}_{1}$ filters. There were moderate relationships of biomass burning tracers with WSOC, water-soluble potassium $(R=0.55-0.65$; Fig. 6) and gaseous $\mathrm{NO}_{\mathrm{x}}, \mathrm{NO}, \mathrm{NO}_{2}(R=0.61-0.75)$.
The time series of levoglucosan, mannosan and galactosan did not agreed with those of the organic acids. That finding is in line with the results of Legrand et al. (2007) who found that regional emissions from vehicles and wood burning are the major sources of carboxylic acids in winter in Europe. In summer, the contribution of the anthropogenic processes to acid concentrations is weaker whereas the contribution of biogenic emissions becomes more important.

\subsection{AMS-PMF factors}

PMF was applied to the high-resolution mass spectra of $\mathrm{OA}$ by varying the number of factors from three to ten. $6 \mathrm{~F}$-solution seemed to be the most representative based on Fig. S3-S8 and the discussion given in Sect. 2.4.2. PMF factors were denoted as hydrocarbon-like OA, biomass burning OA, nitrogen-containing $\mathrm{OA}$ and three oxygenated OAs (OOA-a, OOA-b and OOA-c). There is also a simple estimation method based on the unit mass resolution (UMR) tracer $m / z$ 's that can provide a first-order approximation of the PMF components (Aiken et al., 2009; Ng et al., 2011). The comparison of PMF factors to the rapid estimation of AMS-PMF components from UMR tracer $m / z$ for the SPC data is shown in Fig. S10.

MS profiles and time series of the PMF factors are shown in Fig. 7. Largest concentrations were detected for OOAa $(26 \%)$, HOA $(24 \%)$, and OOA-c (22\%; Fig. 8a). OOAb constituted $13 \%$ of OA whereas BBOA and N-OA composed 8 and $7 \%$ of OA, respectively. HOA spectra was somewhat similar to that measured in Pittsburgh, Zurich and Mexico city (Zhang et al., 2005; Lanz et al., 2007; Aiken et al., 2009) with the MS dominated by the ion series of $\mathrm{C}_{n} \mathrm{H}_{2 n-1}^{+}$ and $\mathrm{C}_{n} \mathrm{H}_{2 n+1}^{+}$, characteristics of OA mass spectra from primary emission sources (Canagaratna et al., 2004; Mohr et al., 2009). Compared with a standard UMR mass spectra profile for HOA obtained from 15 urban data sets ( $\mathrm{Ng}$ et al., 2011), HOA was more oxidized in this study (higher $m / z 44$ in Fig. S11).

HOA had a high $\mathrm{H}: \mathrm{C}$ ratio and low $\mathrm{O}: \mathrm{C}$ and $\mathrm{OM}: \mathrm{OC}$ ratios being the least oxygenated PMF factor (Fig. 8b). HOA had a clear diurnal trend with the highest concentration detected at 10:00 (Fig. 8c). After that the concentration decreased sharply likely caused by the break-up of the nocturnal inversion layer. The concentrations started to build up again $\sim$ 19:00. HOA concentration did not agree with any of the AMS species but it agreed well with EC analyzed from the $\mathrm{PM}_{1}$ filters (Table S2). It also compared well with WSOC and potassium (BLPI and $\mathrm{PM}_{1}$ filters) as well as biomass burning tracers, levoglucosan mannosan and galactosan $\left(\mathrm{PM}_{1}\right.$ filters), suggesting that HOA probably had some connection to BBOA. The correlation coefficients between $\mathrm{HOA}$ and $\mathrm{NO}_{\mathrm{x}} / \mathrm{NO} / \mathrm{NO}_{2}$ were quite small $(R=0.46-0.54)$ but almost all the details of the time trends of HOA were captured by the variability of $\mathrm{NO}_{\mathrm{x}}, \mathrm{NO}$ and $\mathrm{NO}_{2}$ (not shown). It 

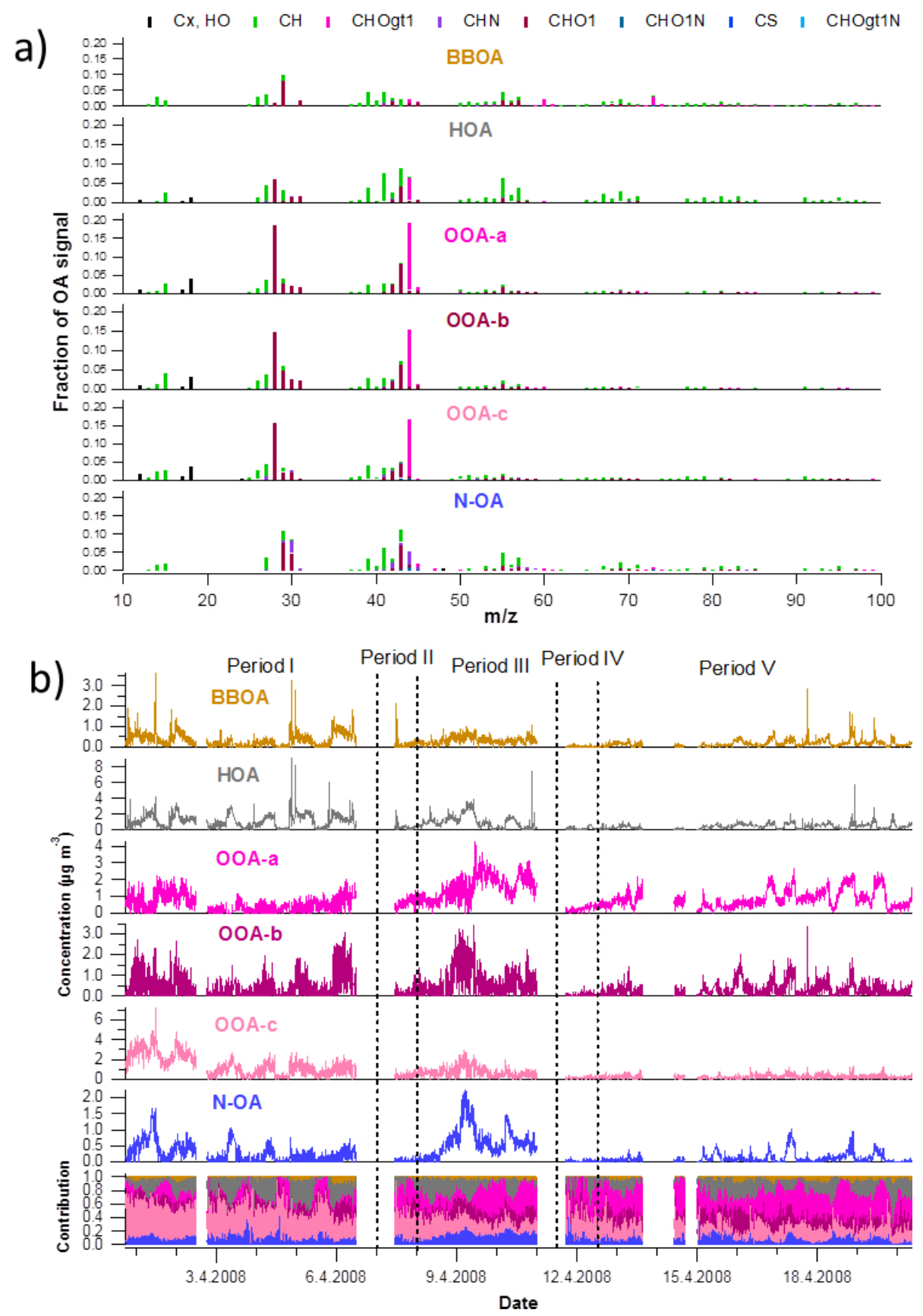

Fig. 7. High-resolution mass spectra for HOA, BBOA, three OOAs, and N-OA (a), their time series and the contribution to total organics (b).

seems that HOA mostly originated from the fossil fuel combustion.

All three OOAs had quite similar mass spectra but as their time series and diurnal trends were rather different, they were considered as separate PMF factors instead of combining them all to one OOA. In terms of MS all OOAs had the strongest signal at $m / z 27.995\left(\mathrm{CO}^{+}\right)$and $43.99\left(\mathrm{CO}_{2}^{+}\right)$but the fraction of $\mathrm{CO}_{2}^{+}$was highest for OOA-a and lowest for OOA-b. OOA-a had also more signal at $43.018\left(\mathrm{C}_{2} \mathrm{H}_{3} \mathrm{O}^{+}\right)$ being overall more oxidized factor than OOA-b and OOA$\mathrm{c}$ (higher $\mathrm{O}: \mathrm{C}$ and $\mathrm{OM}$ : OC ratios, Fig. 8b). Compared with the standard UMR mass spectra profiles from urban sites $(\mathrm{Ng}$ et al., 2011) all OOAs had MS similar to LV-OOA (Fig. S11).

OOA-a had only a small diurnal variation with slightly higher concentrations and mass contributions in the afternoon than in the morning and in the evening (Fig. 8c). The concentrations of OOA-a were low in Period I because in those days background air was very clean. Concentrations were high in Period III when local sources (traffic, biomass 


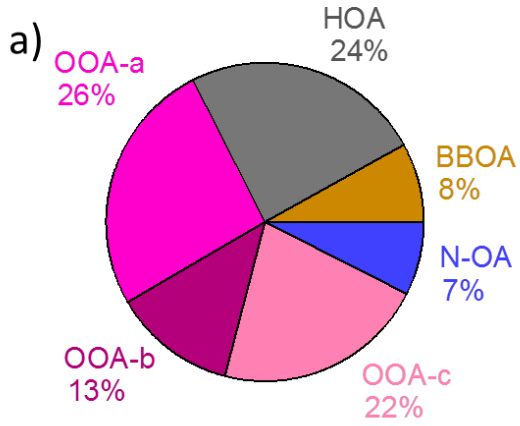

b)

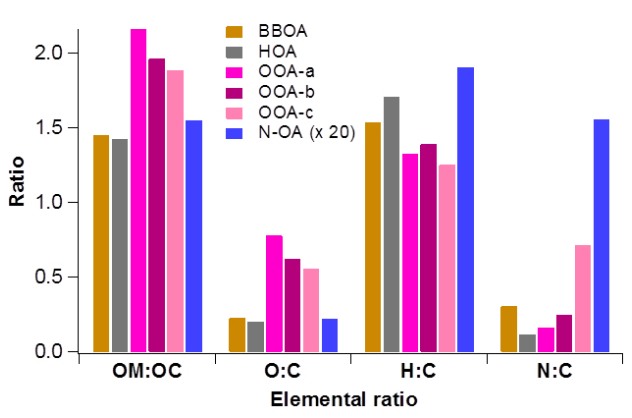

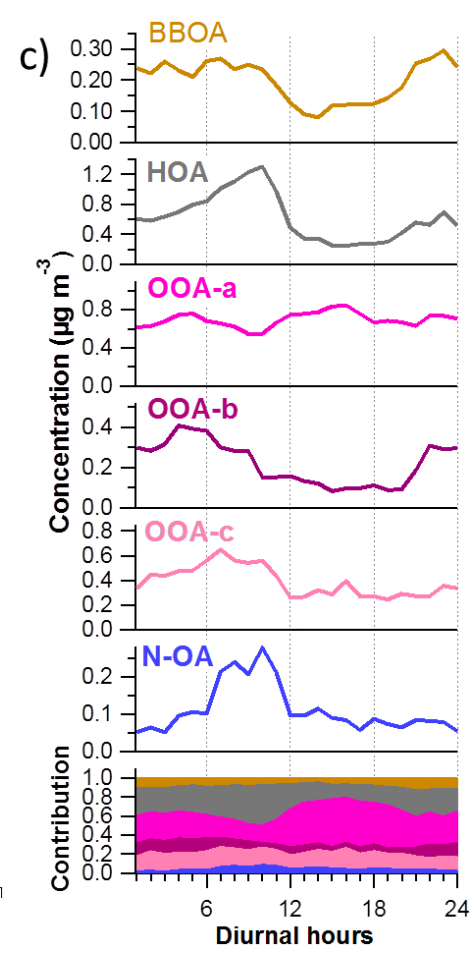

Fig. 8. Campaign-mean contributions (a), elemental composition (b) and diurnal trends for six PMF factors.

burning) and a regional component coexisted. OOA-a had high background concentrations in Period V and also enhancements during the mixing layer formation (Sect. 3.4). OOA-b had a lot of short-term variation but on average, the concentrations of OOA-b were quite even at different periods. OOA-c concentration clearly decreased over the course of the campaign. The highest concentrations for OOA-c were observed in the first two days of the campaign but after that the concentrations declined gradually. The diurnal trends for OOA-b and OOA-c indicated them to be mostly from local sources. OOA-b had the highest concentrations in the morning and during the night with a clear dip during the day. Similar to OOA-b, OOA-c also had the largest concentration in the morning, but differently from OOA-b, the concentration did not increase after sunset. Instead it started to rise after midnight. In terms of diurnal contributions, the contribution of OOA-c to OA was stable throughout the day whereas the contribution of OOA-b was lower in the afternoon than in the other times of the day.

As expected for a regional component, the concentration of OOA-a agreed better with the concentration of sulfate than other OOAs (Table S2). OOA-a also compared well with MSA and chloride suggesting it to originate from sources in the Mediterranean basin rather than in continental Europe. Of all OOAs, OOA-a had clearly smallest correlation coefficient with the carbonaceous species WSOC, EC and OC analyzed from the $\mathrm{PM}_{1}$ filters but it had a good agreement with maleic acid that had different time trends from the other acids (Sect. 3.2.2). OOA-b agreed with the semivolatile inorganic compounds, nitrate and ammonium. OOA-c had the largest correlation coefficients with WSOC, EC, OC, organic acids, except maleic acid, and biomass burning components, levoglucosan, mannosan and galactosan and potassium.

BBOA had the strongest signals at $m / z 29.003\left(\mathrm{CHO}^{+}\right)$ $39.023\left(\mathrm{C}_{3} \mathrm{H}_{3}^{+}\right)$and $41.039\left(\mathrm{C}_{3} \mathrm{H}_{5}^{+}\right.$; Fig. 7a). There was also a high signal at $m / z 60.021\left(\mathrm{C}_{2} \mathrm{H}_{4} \mathrm{O}_{2}^{+}\right)$and $73.029\left(\mathrm{C}_{3} \mathrm{H}_{5} \mathrm{O}_{2}^{+}\right)$ that are characteristic $m / z$ 's for biomass combustion (Alfarra et al., 2007). Compared to the UMR profile of BBOA from $\mathrm{Ng}$ et al. (2011), BBOA had lower signal at $m / z 43$ and 44 (Fig. S11). Regarding biomass burning-related $m / z$ 's, the fraction of $m / z \quad 60$ was similar to that of $\mathrm{Ng}$ et al. (2011) whereas $m / z 73$ was higher at SPC. BBOA had quite low $\mathrm{OM}: \mathrm{OC}$ and $\mathrm{O}: \mathrm{C}$ ratios (1.45 and 0.23 , respectively) but slightly larger $\mathrm{H}: \mathrm{C}$ ratio than OOAs (1.53; Fig. 8b). Compared to BBOA factor observed in Mexico (Aiken et al., 2009), BBOA at SPC was slightly less oxygenated than in Mexico City (OM:OC and O:C ratios of 1.55 and 0.30 in Mexico City, respectively). Similarly to HOA and OOA-b, the lowest BBOA concentrations were observed in the afternoon whereas the highest concentrations were obtained during the late evening $(\sim 23: 00)$.

The concentration of BBOA agreed well with OC, WSOC and most of the organic acids, except maleic and azelaic acid. It also had a good agreement with the biomass burning tracers, MAs (levoglucosan, mannosan and galactosan) and potassium. The relationship between BBOA and the sum 


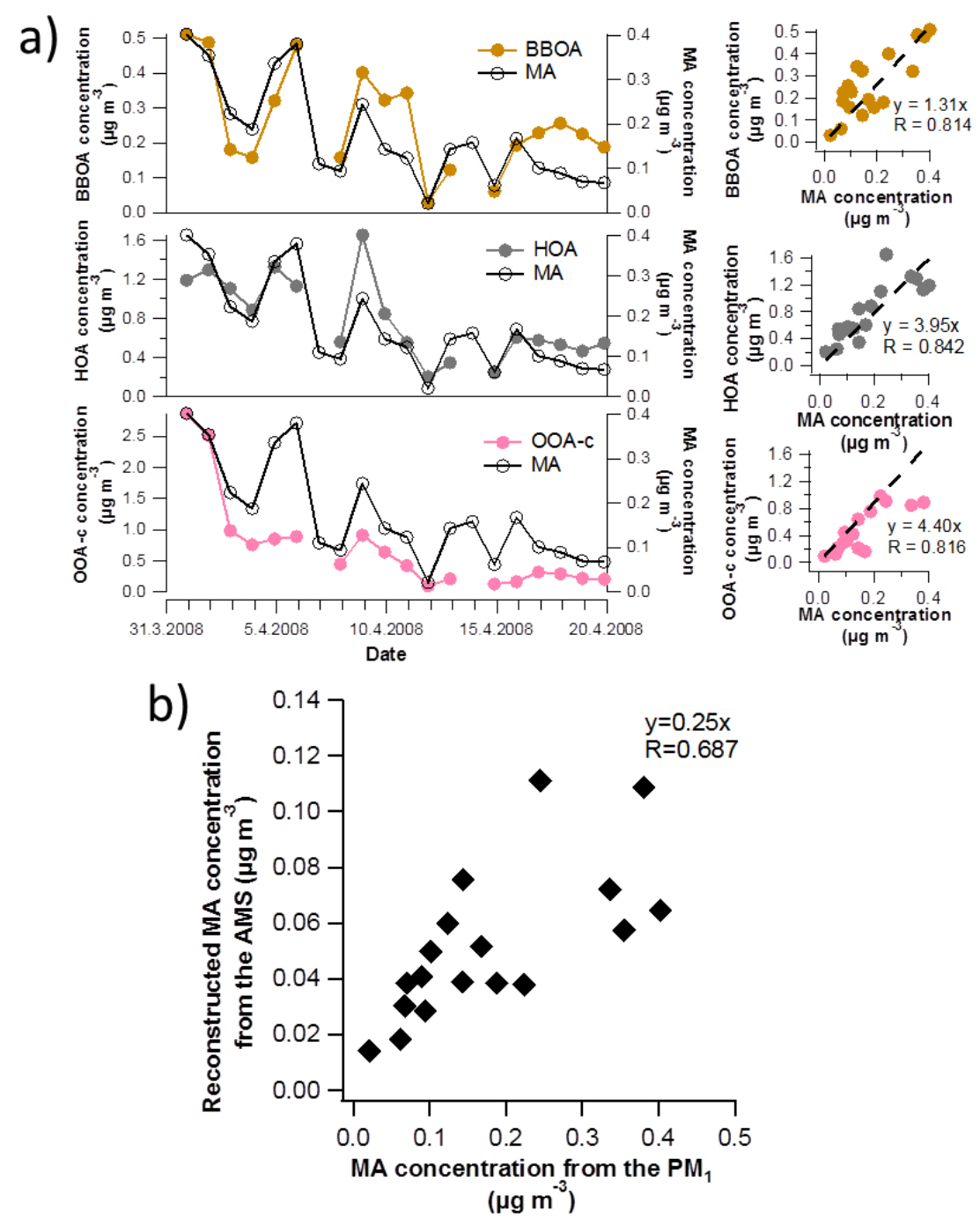

Fig. 9. Time series of three PMF factors compared with the sum of monosaccharide anhydrides (MA; levoglucosan, mannosan and galactosan) analyzed from the $\mathrm{PM}_{1}$ filters (a) and the comparison of anhydrosugars analyzed from the $\mathrm{PM}_{1}$ filters with the hypothetical anhydrosugars computed from the AMS data by using $\mathrm{C}_{2} \mathrm{H}_{4} \mathrm{O}_{2}^{+}$(b). HR-ToF-AMS data was averaged over the $\mathrm{PM}_{1}$ filter sampling periods.

of MAs is shown in Fig. 9a. On average, levoglucosan was present at $\sim 61 \%$ of BBOA which was a much higher percentage than obtained previously for ambient aerosol (e.g. $6.1 \%$ in Mexico city; Aiken et al., 2009) or typically found in biomass burning emissions (Schmidl et al., 2008). As already mentioned, levoglucosan compared well with HOA $(R=0.837)$ and OOA-c $(R=0.820)$. OOA-c was likely to be either oxygenated fraction of biomass burning primary $\mathrm{OA}$, that was only slightly processed, or very freshly formed SOA with a timescale of a few hours. The good agreement between HOA and levoglucosan concentrations probably resulted from the fact that they were both primary components. They had similar mechanisms of accumulation in the boundary layer and therefore alike diurnal trends. Regarding the correlations between levoglucosan and PMF factors, it should be noted here that the sampling time for the $\mathrm{PM}_{1}$ fil- ters was $24 \mathrm{~h}$ meaning that all the details of the levoglucosan concentrations were lost in the filter sampling. Besides similar sources or atmospheric processing, correlations between levoglucosan and PMF factors may also indicate the difference between the air masses or meteorological conditions.

The concentration of anhydrosugars (sum of levoglucosan, mannosan and galactosan) was constructed from the AMS data by using only $\mathrm{C}_{2} \mathrm{H}_{4} \mathrm{O}_{2}^{+}(\mathrm{m} / z$ 60.021; Lee et al., 2010). It was assumed that $\mathrm{C}_{2} \mathrm{H}_{4} \mathrm{O}_{2}^{+}$was present at $0.3 \%$ of OA without biomass burning influence (Aiken et al., 2009), and therefore that fraction was subtracted from the concentration of $\mathrm{C}_{2} \mathrm{H}_{4} \mathrm{O}_{2}^{+}$. In the study of Aiken et al. (2009) they measured that $\mathrm{C}_{2} \mathrm{H}_{4} \mathrm{O}_{2}^{+}$comprised $14.1,13.8$ and $12.1 \%$ of the total ion fragment pattern for levoglucosan, mannosan and galactosan, respectively. These ratios were used together with the ratios of levoglucosan, mannosan and galactosan obtained 
from the $\mathrm{PM}_{1}$ filter samples to reconstruct anhydrosugar concentration from the AMS data. On average AMS anhydrosugars contributed $25 \%$ of the anhydrosugars determined from the filter samples (Fig. 9b). They had somewhat correlation, but especially for the large concentrations, the deviation between two measurements was notable. Lower AMS anhydrosugars than anhydrosugars analyzed from the filters was in contrast to the study of Lee et al. (2010) in which they found that $\mathrm{C}_{2} \mathrm{H}_{4} \mathrm{O}_{2}^{+}$signal was clearly higher than can be explained by the three anhydrosugars in the laboratory studies indicating that there were other structurally similar molecules that produce $\mathrm{C}_{2} \mathrm{H}_{4} \mathrm{O}_{2}^{+}$. It is very difficult to try to explain the lack of $\mathrm{C}_{2} \mathrm{H}_{4} \mathrm{O}_{2}^{+}$in our study since standard anhydrosugar compounds have not been analyzed with the instrument. However, this discrepancy raises a question about the similarity of AMS instruments and the need of instrument intercomparisons.

The sixth factor was identified as nitrogen-containing OA based on its mass spectra. In N-OA MS the highest signal was at $m / z 29.003\left(\mathrm{CHO}^{+}\right), 41.039\left(\mathrm{C}_{3} \mathrm{H}_{5}^{+}\right)$and 43.018 $\left(\mathrm{C}_{2} \mathrm{H}_{3} \mathrm{O}^{+}\right)$but the highest nitrogen-containing fragments were at $\mathrm{m} / z 27.011\left(\mathrm{CHN}^{+}\right), 29.027\left(\mathrm{CH}_{3} \mathrm{~N}^{+}\right), 30.034$ $\left(\mathrm{CH}_{4} \mathrm{~N}^{+}\right.$; Fig. S12a), $31.042\left(\mathrm{CH}_{5} \mathrm{~N}^{+}\right), 41.027\left(\mathrm{C}_{2} \mathrm{H}_{3} \mathrm{~N}^{+}\right)$, $42.034\left(\mathrm{C}_{2} \mathrm{H}_{4} \mathrm{~N}^{+}\right.$; Fig. S12b), $43.042\left(\mathrm{C}_{2} \mathrm{H}_{5} \mathrm{~N}^{+}\right), 44.05$ $\left(\mathrm{C}_{2} \mathrm{H}_{6} \mathrm{~N}^{+}\right), 45.058\left(\mathrm{C}_{2} \mathrm{H}_{7} \mathrm{~N}^{+}\right), 56.05\left(\mathrm{C}_{3} \mathrm{H}_{6} \mathrm{~N}^{+}\right)$and 58.066 $\left(\mathrm{C}_{3} \mathrm{H}_{8} \mathrm{~N}^{+}\right)$. In total, these eleven nitrogen-containing fragments comprised $14 \%$ of the total N-OA signal. Highest concentration of N-OA was observed during Period III, on 9 April, together with the elevated concentrations of nitrate and ammonium. Overall, N-OA compared well with nitrate and ammonium throughout the campaign (Table S2) with a similar diurnal trend having the accumulation of N-OA in the morning and the sharp decrease during the nocturnal surface layer break-up suggesting a local source. Comparing $\mathrm{N}-\mathrm{OA}$ to the compounds analyzed from the BLPI and $\mathrm{PM}_{1}$ samples, N-OA concentration agreed with that of chloride $\left(\mathrm{PM}_{1}\right)$, potassium $\left(\mathrm{PM}_{1}\right)$ and MSA (BLPI and $\left.\mathrm{PM}_{1}\right)$. The correlations with those components, however, indicate some contribution from the marine sources. Previously, a nitrogencontaining OA-PMF factor has been found in e.g. Mexico City (Aiken et al., 2009) and New York (Sun et al., 2011).

As already mentioned, both OOA-a and N-OA agreed well with MSA. They both have a signal for $\mathrm{CH}_{3} \mathrm{SO}_{2}^{+}$at $m / z 78.985$ with its contribution to the total OA signal being 0.11 and $0.075 \%$ for N-OA and OOA-a, respectively. Those fractions were more than 100 times higher than the fraction of $\mathrm{CH}_{3} \mathrm{SO}_{2}^{+}$for the other PMF factors. N-OA had also a signal for $\mathrm{CHS}^{+}$at $m / z 44.9799$ with a similar contribution to $\mathrm{CH}_{3} \mathrm{SO}_{2}^{+}$but the signal of $\mathrm{CHS}^{+}$was not pronounced for OOA-a. MSA has previously measured by a unit mass resolution AMS over the north Pacific Ocean (Phinney et al., 2006).

As expected, N-OA had the highest $\mathrm{N}: \mathrm{C}$ ratio $(0.078)$ but it also had a large $\mathrm{H}: \mathrm{C}$ ratio (1.91; Fig. 8b) indicat- ing a notable contribution from hydrocarbon fragments. Both the $\mathrm{N}: \mathrm{C}$ and $\mathrm{H}: \mathrm{C}$ ratios were higher than those found for nitrogen-containing factor in Mexico City (0.06 and 1.80; Aiken et al., 2009) and in New York (0.053 and 1.50; Sun et al., 2011). In the study conducted in South China, The Pearl River Delta, they did not found a separate factor for nitrogen-containing OA, however, their BBOA factor had a large $\mathrm{N}$ : C ratio (0.053; Huang et al., 2011). N-OA was more oxygenated at SPC than in Mexico City indicated by higher OM : OC and O : $\mathrm{C}$ ratios at SPC (1.55 and 0.22 at SPC, respectively). Besides N-OA, also OOA-c had some nitrogencontaining fragments with a clear $\mathrm{N}: \mathrm{C}$ ratio $(0.036)$.

The fractions of $m / z 44$ and 43 ( $\mathrm{f}_{44}$ and $\mathrm{f}_{43}$, respectively) from the unit mass resolution AMS data can be used to assess the aging of the OA components in the atmosphere. $\mathrm{f}_{44}$ and $\mathrm{f}_{43}$ data from SPC is shown in Fig. S13. As it can be seen from Fig. S13, $\mathrm{f}_{44}$ and $\mathrm{f}_{43}$ ranged from 0.05 to 0.20 and 0.03 to 0.1 , averaging at 0.12 and 0.067 , respectively, for the whole OA. At the beginning of the period (blue) $\mathrm{f}_{43}$ was slightly higher than at the end of the campaign (red). For $\mathrm{f}_{44}$ there was no clear evolution during the campaign. The locations of the PMF factors in $\mathrm{f}_{44}, \mathrm{f}_{43}$ space show how much their oxidation properties vary. As expected, OOAs had large $\mathrm{f}_{44}$ values whereas $\mathrm{f}_{44}$ was significantly smaller for BBOA, $\mathrm{HOA}$ and N-OA. N-OA had much larger $\mathrm{f}_{43}$ than BBOA. Compared to the results of $\mathrm{Ng}$ et al. (2010), all OOAs were located in LV-OOA region. At the same area there were also HULIS samples that consist of organic macromolecular compounds possessing similar properties to those of fulvic and humic acids (Graber and Rudich, 2006).

\subsection{Mixing layer development}

The effect of boundary layer meteorology on aerosol chemical composition was investigated in detail by selecting three representative days when the break-up of nocturnal surface layer occurred almost at the same time of the day at 10:00 UTC $+1 \mathrm{~h}$ (11:00 at local summer time). These days were selected based on the time series of the AMS species and the mixing layer height from the lidar measurements. Selected days were 4, 5 and 17 April, and they are indicated as arrows and asterisks in Fig. 2a.

The time evolution from 06:00 to 14:00 is presented for the mixing layer height, HR-ToF-AMS species, PMF factors and elemental ratios in Fig. 10. The selected three days were averaged together in Fig. 10 but in Table 1 the concentration ratios for before-to-after the break-up are shown for each day separately. Of the AMS species, the concentration of nitrate decreased most significantly during the break-up (Fig. 10a) suggesting that all nitrate was from the local sources. Nitrate concentration was 17 times lower after the break-up, on average, however, there was a large case-to-case variation (Table 1). For organics, ammonium and chloride the effect of break-up was large but significantly less pronounced than for nitrate whereas for sulfate only during the first case day 

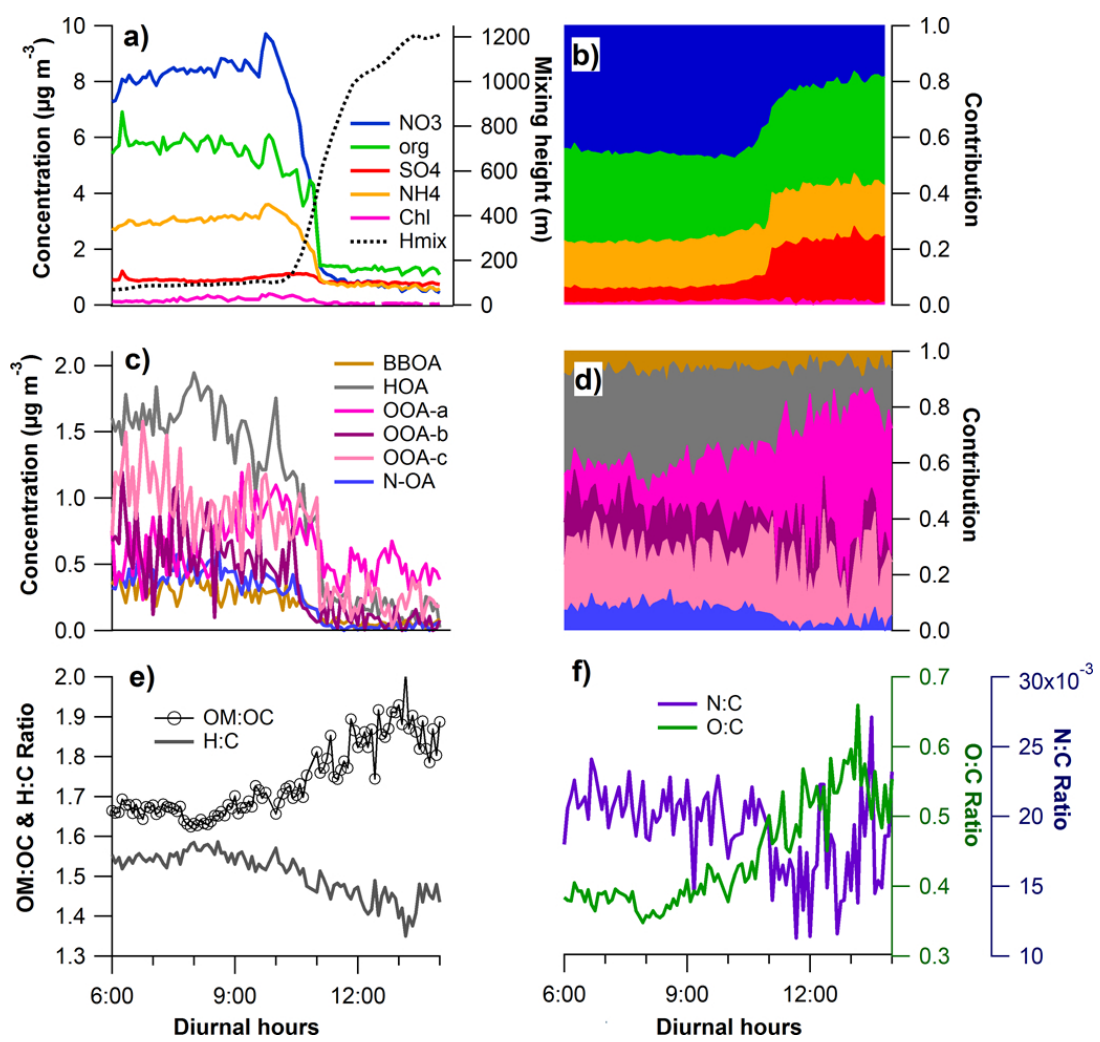

Fig. 10. HR-ToF-AMS species concentrations (a) and contributions (b), PMF factor concentrations (c) and contributions (d), and elemental ratios (e-f) during the nocturnal surface layer break-up. The development of the mixing layer height (Hmix) is shown in (a). Three cases, indicated as arrows in Fig. 2a, were averaged.

Table 1. The ratios of concentrations and species mass contributions before and after the nocturnal surface layer break-up. Three days (4, 5 and 17 April) were selected. Concentrations/ratios before the break-up were calculated by averaging the data before the break-up from 06:00 to $09: 30$ and after the break-up from 11:30 to 14:00.

\begin{tabular}{|c|c|c|c|c|c|c|c|}
\hline \multirow{2}{*}{$\begin{array}{l}\text { Species } \\
\mu \mathrm{g} \mathrm{m}^{-3}\end{array}$} & \multicolumn{3}{|c|}{ before/after Ratio } & \multirow[t]{2}{*}{ Ratios } & \multicolumn{3}{|c|}{ before/after Ratio } \\
\hline & 4 April & 5 April & 17 April & & 4 April & 5 April & 17 April \\
\hline $\mathrm{NO}_{3}$ & 31.4 & 2.76 & 17.4 & $\mathrm{NO}_{3}$ to mass & 3.16 & 1.16 & 1.56 \\
\hline $\mathrm{SO}_{4}$ & 2.32 & 0.85 & 1.04 & $\mathrm{SO}_{4}$ to mass & 0.21 & 0.35 & 0.38 \\
\hline Org & 7.93 & 3.44 & 4.08 & Org to mass & 0.74 & 1.41 & 0.79 \\
\hline $\mathrm{NH}_{4}$ & 9.39 & 1.50 & 5.96 & $\mathrm{NH}_{4}$ to mass & 0.87 & 0.63 & 0.99 \\
\hline Chl & 7.32 & 1.71 & 2.94 & Chl to mass & 1.52 & 1.28 & 1.74 \\
\hline BBOA & 10.83 & 5.33 & 5.15 & $\mathrm{BBOA}$ to $\mathrm{OA}$ & 1.32 & 1.52 & 1.19 \\
\hline $\mathrm{HOA}$ & 9.03 & 11.60 & 6.18 & HOA-b to OA & 1.38 & 3.48 & 1.46 \\
\hline OOA-a & 1.20 & 0.64 & 1.91 & OOA-a to OA & 0.14 & 0.19 & 0.45 \\
\hline OOA-b & 5.71 & 2.91 & 14.34 & OOA-b to OA & 0.80 & 0.88 & 3.39 \\
\hline OOA-c & 10.52 & 2.88 & 3.61 & OOA-c to OA & 1.49 & 0.81 & 0.88 \\
\hline \multirow[t]{5}{*}{$\mathrm{N}-\mathrm{OA}$} & 10.09 & 8.58 & 23.68 & $\mathrm{~N}-\mathrm{OA}$ to $\mathrm{OA}$ & 1.27 & 2.41 & 5.48 \\
\hline & & & & $\mathrm{OM}: \mathrm{OC}$ & 0.92 & 0.86 & 0.91 \\
\hline & & & & $\mathrm{O}: \mathrm{C}$ & 0.76 & 0.62 & 0.77 \\
\hline & & & & $\mathrm{H}: \mathrm{C}$ & 1.04 & 1.11 & 1.09 \\
\hline & & & & $\mathrm{N}: \mathrm{C}$ & 1.14 & 0.93 & 1.64 \\
\hline
\end{tabular}


(4 April) the concentration decreased because of the break-up of the stable nocturnal surface layer. The behavior of sulfate can be seen even more clearly from the species-to-mass ratios. The contribution of sulfate to mass (sum of AMS nitrate, sulfate, organics, ammonium and chloride) was three times larger after the break-up than before the break-up on average (Fig. 10b; Table 1). As speculated earlier in Sect. 3.2.1, the origin of sulfate was mostly regional since its concentration remained rather even when a well-mixed layer was developed.

Of six PMF factors, N-OA had the largest change caused by the nocturnal surface layer break-up followed by HOA (Table 1). That was expected since N-OA and HOA were assumed to originate from local traffic emissions. Of OOAs, OOA-b decreased substantially because of the break-up whereas OOA-a showed hardly any change. The contribution of OOA-a to OA was four times higher after the breakup compared to that before it, on average (Fig. 10d). That resulted in much more oxidized $\mathrm{OA}$ in the mixing layer than in the nocturnal surface layer $(\mathrm{OM}: \mathrm{OC}$ and $\mathrm{O}: \mathrm{C}$ ratios in Fig. 10e-f and Table 1). The air above thermal inversions is unaffected by fresh emissions at nighttime and early morning, and therefore its constituents are more aged and oxidized. Nevertheless, the OM: OC and elemental ratios (Fig. 10e-f) did not change sharply during the break-up. The change of OM:OC and elemental ratios was more gradual that indicates that they were affected by other factors than just the development of mixing layer, e.g. SOA formation. The concentrations of BBOA and OOA-c also decreased during the nocturnal surface layer break-up but the change was smaller than for HOA, N-OA and OOA-b.

It is very difficult to quantify the timing and the impact of the entrainment of air from the free troposphere in the surface layer. Probably, the progressive entrainment is a good explanation, considering also the small decrease of sulfate followed by a slow raise. This is likely due to the initial starting of the convection, but when the upper air gets gradually entrained in the mixing layer the concentrations return to the typical mean values.

\section{Summary and conclusions}

In this study, the chemistry of submicron particles was investigated in the Po Valley region, Italy in spring 2008. Organic acids and biomass burning tracers were measured offline by using 24-h filter sampling. More comprehensive particle chemistry was achieved by using the Aerodyne HR-ToFAMS and analyzing the AMS data by PMF. Combining the filter and AMS results elucidated new features and sources of organic aerosol in the Po Valley region. This was the first time when the high mass resolution and source-related aerosol chemistry was examined in the Po Valley region with this extent.
The oxidation state of organic aerosol in the Po Valley region was examined by studying the PMF factors from the AMS data as well as analyzing the organic acids from the filter samples. On average, the OM: OC ratio was 1.77 for OA, the oxidation state depending on the time of the day and varying from one PMF factor to another. In total, six PMF factors were obtained for organic aerosol at SPC: HOA, BBOA, N-OA and three different OOAs (OOA-a, OOA-b and OOA-c). As expected, the three OOAs were the most oxygenated factors. OOA-c that was the least oxygenated factor of OOAs but it had the largest correlation coefficient with the organic acids. It was speculated that OOA-c was associated with biomass burning supported by the fact that also levoglucosan agreed well with OOA-c. OOA-a was the most oxygenated OA-factor and it has similar time series with the marine-related components: sulfate, chloride and MSA. The mass spectra of OOA-a had fragments from the organic sulfur compounds, $\mathrm{CHS}^{+}$and $\mathrm{CH}_{3} \mathrm{SO}_{2}^{+}$. Sulfur components were also found in the MS of N-OA but overall, N-OA had more significant contribution from the nitrogen-containing fragments like $\mathrm{CH}_{4} \mathrm{~N}^{+}, \mathrm{C}_{2} \mathrm{H}_{4} \mathrm{~N}^{+}$and $\mathrm{C}_{2} \mathrm{H}_{6} \mathrm{~N}^{+}$. To conclude, $\mathrm{OA}$ in the Po Valley region was a complex mixture of components from both local and regional sources. A large fraction of it originated from anthropogenic sources, like traffic and biomass burning, but a considerable part of it was likely to be e.g. marine-related.

One special feature at SPC, that has not been studied much in terms of aerosol chemical composition, was a break-up of the nocturnal surface layer in a daytime. The effect of the break-up was most evident for nitrate and N-OA suggesting the similarity of their sources or formation processes. For sulfate and OOA-a the fraction in the submicron particle mass or OA was three times larger after the break-up than before it. The origin of sulfate and OOA-a was mostly regional since their concentration was rather constant even when the nocturnal surface layer air was diluted with aloft layers by turbulent mixing at late morning. That resulted in much more oxidized $\mathrm{OA}$ in the daytime mixing layer than in the nocturnal surface layer. Particles above the surface layer were aged and therefore also suspected to be more oxidized than the aerosol in the surface layer.

The most important new finding of this investigation was the detailed, high time resolution, source apportionment of organic aerosol in the Po Valley, with links to the different meteorological conditions and the time of the day (photochemical conditions and PBL evolution). This study showed that a large fraction of aerosol was from local sources, i.e., providing particles reaching the site after a few hours transport at surface level in weak wind conditions, but even in a highly polluted area like Po Valley, there is a contribution from a regional origin, especially evident in the hours of the day when the PBL was well developed and entrained air from the layers traveling aloft. These findings have implications on air pollution and related health issues as the understanding of the origin of pollution was greatly improved. The 
composition and sources of atmospheric aerosol has been examined in the Po Valley region for decades, however, most of the studies rest on the filter measurements collected on daily basis. This paper enhances the time scale by explaining the chemistry on hourly basis and over the variation in the boundary layer height.

This study did not include time resolved black carbon measurements. As black carbon is known to be a crucial component in terms of climate change and air quality, future research in Po Valley should be aimed, in addition to organic aerosol, also at the sources and the composition of black carbon. At the moment, there are methods available that enable the detailed investigation of the chemical and physical properties of particles containing black carbon (Onasch et al., 2012).

\section{Supplementary material related to this article is available online at: http://www.atmos-chem-phys.net/12/ 8401/2012/acp-12-8401-2012-supplement.pdf.}

Acknowledgements. This work was supported by the European Integrated Project on Aerosol Cloud Climate and Air Quality Interactions (EUCAARI). We acknowledge Emilia-Romagna regional agency for environmental protection (ARPA-ER) for providing trace gas concentration data $\left(\mathrm{NO}_{\mathrm{x}}\right.$ and $\left.\mathrm{O}_{3}\right)$, and Ari Laaksonen (University of Kuopio) for the $\mathrm{SO}_{2}$ measurements. Samara Carbone also acknowledges the Graduate School in Physics, Chemistry, Biology and Meteorology of Atmospheric Composition and Climate Change (University of Helsinki).

Edited by: V.-M. Kerminen

\section{References}

Aiken, A. C., Salcedo, D., Cubison, M. J., Huffman, J. A., DeCarlo, P. F., Ulbrich, I. M., Docherty, K. S., Sueper, D., Kimmel, J. R., Worsnop, D. R., Trimborn, A., Northway, M., Stone, E. A., Schauer, J. J., Volkamer, R. M., Fortner, E., de Foy, B., Wang, J., Laskin, A., Shutthanandan, V., Zheng, J., Zhang, R., Gaffney, J., Marley, N. A., Paredes-Miranda, G., Arnott, W. P., Molina, L. T., Sosa, G., and Jimenez, J. L.: Mexico City aerosol analysis during MILAGRO using high resolution aerosol mass spectrometry at the urban supersite (T0) - Part 1: Fine particle composition and organic source apportionment, Atmos. Chem. Phys., 9, 6633-6653, doi:10.5194/acp-9-6633-2009, 2009.

Alfarra, M. R., Coe, H., Allan, J. D., Bower, K. N., Boudries, H., Canagaratna, M. R., Jimenez, J. L., Jayne, J. T., Garforth, A. A., Li, S.-M., and Worsnop, D. R.: Characterization of urban and ruralorganic particulate in the Lower Fraser Valley using two Aerodyne Aerosol Mass Spectrometers, Atmos. Environ., 38, 57455758, 2004.

Alfarra, M. R., Prevot, A. S. H., Szidat, S., Sandradewi, J., Weimer, S., Lanz, V. A., Schreiber, D., Mohr, M., and Baltensperger, U.: Identification of the Mass Spectral Signature of Organic Aerosols from Wood Burning Emissions, Environ. Sci. Technol., 41, 5770-5777, 2007.
Allan, J. D., Bower, K. N., Coe, H., Boudries, H., Jayne, J. T., Canagaratna, M. R., Millet, D. B., Goldstein, A. H., Quinn, P. K., Weber, R. J., and Worsnop, D. R.: Submicron aerosol composition at Trinidad Head, California, during ITCT 2K2: Its relationship with gas phase volatile organic carbon and assessment of instrument performance, J. Geophys. Res., 109, D23S24, doi:10.1029/2003JD004208, 2004.

Allan, J. D., Alfarra, M. R., Bower, K. N., Coe, H., Jayne, J. T., Worsnop, D. R., Aalto, P. P., Kulmala, M., Hyötyläinen, T., Cavalli, F., and Laaksonen, A.: Size and composition measurements of background aerosol and new particle growth in a Finnish forest during QUEST 2 using an Aerodyne Aerosol Mass Spectrometer, Atmos. Chem. Phys., 6, 315-327, doi:10.5194/acp-6-315-2006, 2006.

Allan, J. D., Williams, P. I., Morgan, W. T., Martin, C. L., Flynn, M. J., Lee, J., Nemitz, E., Phillips, G. J., Gallagher, M. W., and Coe, H.: Contributions from transport, solid fuel burning and cooking to primary organic aerosols in two UK cities, Atmos. Chem. Phys., 10, 647-668, doi:10.5194/acp-10-647-2010, 2010.

Berner, A. and Lürzer, C.: Mass size distributions of traffic aerosols at Vienna, J. Phys. Chem., 84, 2079-2083, 1980.

Canagaratna, M. R., Jayne, J. T., Ghertner, D. A., Herndon, S., Shi, Q., Jimenez, J. L., Silva, P. I., Williams, P., Lanni, T., Drewnick, F., Demerjian, K. L., Kolb, C. E., and Worsnop, D. R.: Chase Studies of Particulate Emissions from in-use New York City Vehicles, Aerosol Sci. Technol., 38, 555-573, 2004.

Canagaratna, M. R., Jayne, J. T., Jimenez, J. L., Allan, J. D., Alfarra, M. R., Zhang, Q., Onasch, T. B., Drewnick, F., Coe, H., Middlebrook, A., Delia, A., Williams, L. R., Trimborn, A. M., Northway, M. J., DeCarlo, P. F., Kolb, C. E., Davidovits, P., and Worsnop, D. R.: Chemical and Microphysical Characterization of Ambient Aerosols with the Aerodyne Aerosol Mass Spectrometer, Mass Spectrom. Rev., 26, 185-222, 2007.

Crosier, J., Allan, J. D., Coe, H., Bower, K. N., Formenti, P., and Williams, P. I.: Chemical composition of summertime aerosol in the Po Valley (Italy), northern Adriatic and Black Sea, Q. J. Roy. Meteorol. Soc., 133, 61-75, 2007.

DeCarlo, P. F., Kimmel, J. R., Trimborn, A., Northway, M. J., Jayne, J. T., Aiken, A. C., Gonin, M., Fuhrer, K., Horvath, T., Docherty, K. S., Worsnop, D. R., and Jimenez, J. L.: Field-deployable, high-resolution, time-of-flight mass spectrometer, Anal. Chem., 78, 8281-8289, 2006.

Decesari, S., Facchini, M. C., Matta, E., Lettini, F., Mircea, M., Fuzzi, S., Tagliavini, E., and Putaud, J.-P.: Chemical features and seasonal variation of fine aerosol water-soluble organic compounds in the Po Valley, Italy, Atmos. Environ., 35, 3691-3699, 2001.

Docherty, K. S., Stone, E. A., Ulbrich, I. M., DeCarlo, P. F., Snyder, D. C., Schauer, J. J., Peltier, R. E., Weber, R. J., Murphy, S. M., Seinfeld, J. H., Eatough, D. J., Grover, B. D., and Jimenez, J. L.: Apportionment of primary and secondary organic aerosols in Southern California during the 2005 study of organic aerosols in riverside (SOAR), Environ. Sci. Technol., 42, 7655-7662, 2008.

Fisseha, R., Dommen, J., Gaeggeler, K., Weingartner, E., Samburova, V., Kalberer, M., and Baltensperger, U.: Online gas and aerosol measurement of water soluble carboxylic acids in Zurich, J. Geophys. Res., 111, D12316, doi:10.1029/2005JD006782, 2006. 
Gilardoni, S., Vignati, E., Cavalli, F., Putaud, J. P., Larsen, B. R., Karl, M., Stenström, K., Genberg, J., Henne, S., and Dentener, F.: Better constraints on sources of carbonaceous aerosols using a combined ${ }^{14} \mathrm{C}$ - macro tracer analysis in a European rural background site, Atmos. Chem. Phys., 11, 5685-5700, doi:10.5194/acp-11-5685-2011, 2011.

Graber, E. R. and Rudich, Y.: Atmospheric HULIS: How humic-like are they? A comprehensive and critical review, Atmos. Chem. Phys., 6, 729-753, doi:10.5194/acp-6-729-2006, 2006.

Hamed, A., Joutsensaari, J., Mikkonen, S., Sogacheva, L., Dal Maso, M., Kulmala, M., Cavalli, F., Fuzzi, S., Facchini, M. C., Decesari, S., Mircea, M., Lehtinen, K. E. J., and Laaksonen, A.: Nucleation and growth of new particles in Po Valley, Italy, Atmos. Chem. Phys., 7, 355-376, doi:10.5194/acp-7-355-2007, 2007.

Hennigan, C. J., Sullivan, A. P., Collett Jr., J. L., and Robinson, A. L.: Levoglucosan stability in biomass burning particles exposed to hydroxyl radicals, Geophys. Res. Lett., 37, L09806, doi:10.1029/2010GL043088, 2010.

Huang, X.-F., He, L.-Y., Hu, M., Canagaratna, M. R., Sun, Y., Zhang, Q., Zhu, T., Xue, L., Zeng, L.-W., Liu, X.-G., Zhang, Y.-H., Jayne, J. T., Ng, N. L., and Worsnop, D. R.: Highly time-resolved chemical characterization of atmospheric submicron particles during 2008 Beijing Olympic Games using an Aerodyne High-Resolution Aerosol Mass Spectrometer, Atmos. Chem. Phys., 10, 8933-8945, doi:10.5194/acp-10-8933-2010, 2010

Huang, X.-F., He, L.-Y., Hu, M., Canagaratna, M. R., Kroll, J. H., Ng, N. L., Zhang, Y.-H., Lin, Y., Xue, L., Sun, T.-L., Liu, X.-G., Shao, M., Jayne, J. T., and Worsnop, D. R.: Characterization of submicron aerosols at a rural site in Pearl River Delta of China using an Aerodyne High-Resolution Aerosol Mass Spectrometer, Atmos. Chem. Phys., 11, 1865-1877, doi:10.5194/acp-11-18652011, 2011.

Huffman, J. A., Jayne, J. T., Drewnick, F., Aiken, A. C., Onasch, T., Worsnop, D. R., and Jimenez, J. L.: Design, Modeling, Optimization, and Experimental Tests of a Particle Beam Width Probe for the Aerodyne Aerosol Mass Spectrometer, Aerosol Sci. Technol., 39, 1143-1163, 2005.

Jayne, J. T., Leard, D. C., Zhang, X., Davidovits, P., Smith, K. A., Kolb, C. E., and Worsnop, D. R.: Development of an Aerosol Mass Spectrometer for Size and Composition, Analysis of Submicron Particles, Aerosol Sci. Technol., 33, 49-70, 2000.

Jimenez, J. L., Canagaratna, M. R., Donahue, N. M., Prevot, A. S. H., Zhang, Q., Kroll, J. H., DeCarlo, P. F., Allan, J. D., Coe, H., Ng, N. L., Aiken, A. C., Docherty, K. S., Ulbrich, I. M., Grieshop, A. P., Robinson, A. L., Duplissy, J., Smith, J. D., Wilson, K. R., Lanz, V. A., Hueglin, C., Sun, Y. L., Tian, J., Laaksonen, A., Raatikainen, T., Rautiainen, J., Vaattovaara, P., Ehn, M., Kulmala, M., Tomlinson, J. M., Collins, D. R., Cubison, M. J., Dunlea, E. J., Huffman, J. A., Onasch, T. B., Alfarra, M. R., Williams, P. I., Bower, K., Kondo, Y., Schneider, J., Drewnick, F., Borrmann, S., Weimer, S., Demerjian, K., Salcedo, D., Cottrell, L., Griffin, R., Takami, A., Miyoshi, T., Hatakeyama, S.,Shimono, A., Sun, J. Y., Zhang, Y. M., Dzepina, K., Kimmel, J. R., Sueper, D., Jayne, J. T., Herndon, S. C., Trimborn, A. M., Williams, R., Wood, E. C., Middlebrook, A. M., Kolb, C. E., Baltensperger, U., and Worsnop, D. R.: Evolution of Organic Aerosols in the Atmosphere, Science, 326, 1525-1529, 2009.
Kawamura, K. and Ikushima K.: Seasonal changes in the distribution of dicarboxylic acids in the urban atmosphere, Environ. Sci. Technol., 27, 2227-2235, doi:10.1021/es00047a033, 1993.

Kawamura, K., Kasukabe, H., and Barrie L. A.: Source and reaction pathways of dicarboxylic acids, ketoacids and dicarbonyls in Arctic aerosols: One year observations, Atmos. Environ., 30, 1709-1722, 1996.

Lanz, V. A., Alfarra, M. R., Baltensperger, U., Buchmann, B., Hueglin, C., and Prévôt, A. S. H.: Source apportionment of submicron organic aerosols at an urban site by factor analytical modelling of aerosol mass spectra, Atmos. Chem. Phys., 7, 15031522, doi:10.5194/acp-7-1503-2007, 2007.

Lanz, V. A., Prévôt, A. S. H., Alfarra, M. R., Weimer, S., Mohr, C., DeCarlo, P. F., Gianini, M. F. D., Hueglin, C., Schneider, J., Favez, O., D'Anna, B., George, C., and Baltensperger, U.: Characterization of aerosol chemical composition with aerosol mass spectrometry in Central Europe: an overview, Atmos. Chem. Phys., 10, 10453-10471, doi:10.5194/acp-10-10453-2010, 2010.

Lee, T., Sullivan, A. P., Mack, L., Jimenez, J. L., Kreidenweis, S. M. Onasch, T. B., Worsnop, D. R., Malm, W., Wold, C. E., Hao, W. M., and Collett Jr., J. L.: Chemical smoke marker emissions during flaming and smoldering phases of laboratory open burning of wildland fuels, Aerosol Sci. Technol., 44, doi:10.1080/02786826.2010.499884, 2010.

Legrand, M., Preunkert, S., Oliveira, T., Pio, C. A., Hammer, S., Gelencsér, A., Kasper-Giebl, A., and Laj, P.: Origin of C2-C5 dicarboxylic acids in the European atmosphere inferred from yearround aerosol study conducted at a west-east transect, J. Geophys. Res., 112, D23S07, doi:10.1029/2006JD008019, 2007.

Matta, E., Facchini, M. C., Decesari, S., Mircea, M., Cavalli, F., Fuzzi, S., Putaud, J.-P., and Dell'Acqua, A.: Mass closure on the chemical species in size-segregated atmospheric aerosol collected in an urban area of the Po Valley, Italy, Atmos. Chem. Phys., 3, 623-637, doi:10.5194/acp-3-623-2003, 2003.

Matthew, B. M., Middlebrook, A. M., and Onasch, T. B.: Collection Efficiencies in an Aerodyne Aerosol Mass Spectrometer as a Function of Particle Phase for Laboratory Generated Aerosols, Aerosol Sci. Technol., 42, 884-898, 2008.

Middlebrook, A. M., Bahreini, R., Jimenez, J. L., and Canagaratna, M. R.: Evaluation of Composition-Dependent Collection Efficiencies for the Aerodyne Aerosol Mass Spectrometer using Field Data, Aerosol Sci. Technol., 46, 258-271, 2012.

Mohr, C. J., Huffman, J. A., Cubison, M. J., Aiken, A. C., Docherty, K. S., Kimmel, J. R., Ulbrich, I. M., Hannigan, M., and Jimenez, J. L.: Characterization of Primary Organic Aerosol Emissions from Meat Cooking, Trash Burning, and Motor Vehicles with High-Resolution Aerosol Mass Spectrometry and Comparison with Ambient and Chamber Observations, Environ. Sci. Technol., 43, 2443-2449, 2009.

Ng, N. L., Canagaratna, M. R., Zhang, Q., Jimenez, J. L., Tian, J., Ulbrich, I. M., Kroll, J. H., Docherty, K. S., Chhabra, P. S., Bahreini, R., Murphy, S. M., Seinfeld, J. H., Hildebrandt, L., Donahue, N. M., DeCarlo, P. F., Lanz, V. A., Prévôt, A. S. H., Dinar, E., Rudich, Y., and Worsnop, D. R.: Organic aerosol components observed in Northern Hemispheric datasets from Aerosol Mass Spectrometry, Atmos. Chem. Phys., 10, 46254641, doi:10.5194/acp-10-4625-2010, 2010.

Ng, N. L., Canagaratna, M. R., Jimenez, J. L., Zhang, Q., Ulbrich, I. M., and Worsnop, D. R.: Real-Time Methods for Estimating 
Organic Component Mass Concentrations from Aerosol Mass Spectrometer Data, Environ. Sci. Technol., 45, 910-916, 2011.

Nolte, C. G., Schauer, J. J, Cass, G. R., and Simoneit, B. R. T.: Highly polar organic compounds present in wood smoke and in the ambient atmosphere, Environ. Sci. Technol., 35, 1912-1919, 2001.

Onasch, T. B., Trimborn, A., Fortner, E. C., Jayne, J. T., Kok, G. L., Williams, L. R., Davidovits, P., and Worsnop, D. R.: Soot Particle Aerosol Mass Spectrometer: Development, Validation, and Initial Application, Aerosol Sci. Technol. 46, 804-817, 2012.

Paatero, P. and Tapper, U.: Positive Matrix Factorization - a Nonnegative Factor Model with Optimal Utilization of ErrorEstimates of Data Values, Environmetrics, 5, 111-126, 1994.

Paglione, M., Facchini, M. C., Finessi, E., Giulianelli, L., Carbone, C., Fuzzi, S., Moretti, F., Tagliavini, E., Hillamo, R., Carbone, S., Saarikoski, S., Worsnop, D., Swietlicki, E., and Decesari, S.: Primary and secondary biomass burning aerosols determined by proton nuclear magnetic resonance (1H-NMR) spectroscopy during the 2008 EUCAARI campaign in the Po Valley (Italy), Atmos. Chem. Phys. Discuss., in preparation, 2012.

Pang, Y., Turpin, B. J., and Gundel, L.: On the importance of organic oxygen for understanding organic aerosol particles, Aerosol Sci. Technol., 40, 128-133, 2006.

Pavuluri, C. N., Kawamura, K., and Swaminathan, T.: Water-soluble organic carbon, dicarboxylic acids, ketoacids, and $\alpha$-dicarbonyls in the tropical Indian aerosols, J. Geophys. Res., 115, D11302, doi:10.1029/2009JD012661, 2010.

Phinney, L., Leaitch, W. R., Lohmann, U., Boudries, H., Worsnop, D. R., Jayne, J. T., Toom-Sauntry, D., Wadleigh, M., Sharma, S., and Shantz, N.: Characterization of the aerosol over the subarctic north east Pacific Ocean, Deep-Sea Res. Pt. II, 53, 24102433, 2006.

Plaza, J., Gómez-Moreno, F. J., Núñez, L., Pujadas, M., and Artiñano, B.: Estimation of secondary organic aerosol formation from semi-continuous OC-EC measurements in a Madrid suburban area, Atmos. Environ., 40, 1134-1147, 2006.

Rogge, W. F., Hildemann, L. M., Mazurek, M. A., Cass, G. R., and Simoneit, B. R. T.: Sources of fine organic aerosol. 1. Charbroilers and meat cooking operations, Environ. Sci. Technol., 25, 1112-1125, 1991.

Rogge, W. F., Hildemann, L. M., Mazurek, M. A., and Cass, G. R.: Sources of fine organic aerosol. 9. pine, oak, and synthetic log combustion in residential fireplaces, Eviron. Sci. Technol., 32, 13-22, 1998.

Saarikoski, S., Sillanpää, M., Sofiev, M., Timonen, H., Saarnio, K., Teinilä, K., Karppinen, A., Kukkonen, J., and Hillamo, R.: Chemical composition of aerosols during a major biomass burning episode over northern Europe in spring 2006: experimental and modelling assessments, Atmos. Environ., 41, 3577-3589, 2007.

Saarikoski, S., Sillanpää, M., Saarnio, K., Hillamo, R., Pennanen, A. S., and Salonen, R. O.: Impact of biomass combustion on urban fine particulate matter in Central and Northern Europe, Water Air Soil Pollut., 191, 265-277, doi:10.1007/s11270-008-9623-1, 2008.

Saarnio, K., Teinilä, K., Aurela, M., Timonen, H., and Hillamo, R.: High-performance anion-exchange chromatography-mass spectrometry method for determination of levoglucosan, mannosan and galactosan in atmospheric fine particulate matter,
Anal. Bioanal. Chem., 398, 2253-2264, doi:10.1007/s00216010-4151-4, 2010.

Schmidl, C., Marr, I. A., Caseiro, A., Kotianová, P., Berner, A., Bauer, H., Kasper-Giebl, A., and Puxbaum, H.: Chemical characterisation of fine particle emissions from wood stove combustion of common woods growing in mid-European Alpine regions, Atmos. Environ., 42, 126-141, 2008.

Seinfeld, J. H. and Pandis, S. N.: Atmospheric Chemistry and Physics, from Air Pollution to Climate Change, New York, Wiley, 1998.

Sillanpää, M., Frey, A., Hillamo, R., Pennanen, A. S., and Salonen, R. O.: Organic, elemental and inorganic carbon in particulate matter of six urban environments in Europe, Atmos. Chem. Phys., 5, 2869-2879, doi:10.5194/acp-5-2869-2005, 2005.

Simoneit, B. R. T., Schauer, J. J., Nolte, C. G., Oros, D. R., Elias, V. O., Fraser, M. P., Rogge, W. F., and Cass, G. R.: Levoglucosan, a tracer for cellulose in biomass burning and atmospheric particles, Atmos. Environ., 33, 173-182, 1999.

Slowik, J. G., Vlasenko, A., McGuire, M., Evans, G. J., and Abbatt, J. P. D.: Simultaneous factor analysis of organic particle and gas mass spectra: AMS and PTR-MS measurements at an urban site, Atmos. Chem. Phys., 10, 1969-1988, doi:10.5194/acp-10-19692010, 2010.

Sofiev, M., Prank, M., and Baklanov, A. (Eds.): Influence of Regional Scale Emissions on Megacity Air Quality, MEGAPOLI Scientific Report 11-12, available at: http://megapoli.dmi.dk/ publ/MEGAPOLI_sr11-12.pdf, 2011.

Sueper, D.: ToF-AMS High Resolution Analysis Software - Pika, availabel at: http://cires.colorado.edu/jimenez-group/wiki/index. php/ToF-AMS_Analysis_Software, 2008.

Sun, Y., Zhang, Q., Macdonald, A. M., Hayden, K., Li, S. M., Liggio, J., Liu, P. S. K., Anlauf, K. G., Leaitch, W. R., Steffen, A., Cubison, M., Worsnop, D. R., van Donkelaar, A., and Martin, R. V.: Size-resolved aerosol chemistry on Whistler Mountain, Canada with a high-resolution aerosol mass spectrometer during INTEX-B, Atmos. Chem. Phys., 9, 3095-3111, doi:10.5194/acp9-3095-2009, 2009.

Sun, Y.-L., Zhang, Q., Schwab, J. J., Demerjian, K. L., Chen, W.N., Bae, M.-S., Hung, H.-M., Hogrefe, O., Frank, B., Rattigan, O. V., and Lin, Y.-C.: Characterization of the sources and processes of organic and inorganic aerosols in New York city with a high-resolution time-of-flight aerosol mass apectrometer, Atmos. Chem. Phys., 11, 1581-1602, doi:10.5194/acp-11-15812011, 2011.

Takegawa, N., Miyakawa, T., Kondo, Y., Jimenez, J. L., Zhang, Q., Worsnop, D. R., and Fukuda, M.: Seasonal and diurnal variations of submicron organic aerosol in Tokyo oserved using the Aerodyne aerosol mass spectrometer, J. Geophys. Res., 111, D11206, doi:10.1029/2005JD006515, 2006.

Takegawa, N., Miyakawa, T., Watanabe, M., Kondo, Y., Miyazaki, Y., Han, S., Zhao, Y., van Pinxteren, D., Bruggemann, E., Gnauk, T., Herrmann, H., Xiao, R., Deng, Z., Hu, M., Zhu, T., and Zhang, Y.: Performance of an Aerodyne Aerosol Mass Spectrometer (AMS) during Intensive Campaigns in China in the Summer of 2006, Aerosol Sci. Technol., 43, 189-204, 2009.

Timonen, H. J., Saarikoski, S. K., Aurela, M. A., Saarnio, K. M., and Hillamo R. E. J.: Water-soluble organic carbon in urban aerosol: concentrations, size distributions and contribution to particulate matter, Boreal Environ. Res., 13, 335-346, 2008. 
Ulbrich, I. M., Canagaratna, M. R., Zhang, Q., Worsnop, D. R., and Jimenez, J. L.: Interpretation of organic components from Positive Matrix Factorization of aerosol mass spectrometric data, Atmos. Chem. Phys., 9, 2891-2918, doi:10.5194/acp-9-2891-2009, 2009.

Volkamer, R., Jimenez, J. L., San Martini, F., Dzepina, K., Zhang, Q., Salcedo, D., Molina, L. T., Worsnop, D. R., and Molina, M. J.: Secondary organic aerosol formation from anthropogenic air pollution: Rapid and higher than expected, Geophys. Res. Lett., 33, L17811, doi:10.1029/2006GL026899, 2006.

Yttri, K. E., Dye, C., Siørdal, L. H., and Braathen O.-A.: Quantification of monosaccharide anhydrides by liquid chromatography combined with mass spectrometry: application to aerosol samples from an urban and a suburban site influenced by small-scale wood burning, J. Air Waste Manage., 55, 1169-1177, 2005.

Zhang, Q., Worsnop, D. R., Canagaratna, M. R., and Jimenez, J. L.: Hydrocarbon-like and oxygenated organic aerosols in Pittsburgh: insights into sources and processes of organic aerosols, Atmos. Chem. Phys., 5, 3289-3311, doi:10.5194/acp-5-32892005, 2005.
Zhang, Q., Jimenez, J. L., Canagaratna, M. R., Allan, J. D., Coe, H., Ulbrich, I., Alfarra, M. R., Takami, A., Middlebrook, A. M., Sun, Y. L., Dzepina, K., Dunlea, E., Docherty, K., DeCarlo, P. F., Salcedo, D., Onasch, T., Jayne, J. T., Miyoshi, T., Shimono, A., Hatakeyama, S., Takegawa, N., Kondo, Y., Schneider, J., Drewnick, F., Weimer, S., Demerjian, K., Williams, P., Bower, K., Bahreini, R., Cottrell, L., Griffin, R. J., Rautiainen, J., and Worsnop, D. R.: Ubiquity and Dominance of Oxygenated Species in Organic Aerosols in Anthropogenically-Influenced Northern Hemisphere Mid-latitudes, Geophys. Res. Lett., 34, L13801, doi:10.1029/2007GL029979, 2007. 